Het er o and I acunary pol yoxovanadate chemi st ry: Synt hesi s, reactivity and structural aspects

\begin{tabular}{|l|l|}
\hline 著者 & Hayashi Yoshi hi to \\
\hline $\begin{array}{l}\text { j our nal or } \\
\text { publ i cat i on t i t l e }\end{array}$ & Coor di nat i on Chemi st ry Revi ews \\
\hline vol une & 255 \\
\hline number & $19-20$ \\
\hline page range & $2270-2080$ \\
\hline year & $2011-10-01$ \\
\hline URL & ht t p: //hdl . handl e. net /2297/29199 \\
\hline
\end{tabular}




\title{
Hetero and lacunary polyoxovanadate chemistry: synthesis, reactivity and structural aspects
}

\author{
Yoshihito Hayashi $^{1^{*}}$ \\ Department of Chemistry, Kanazawa University, Kakuma, Kanazawa, 920-1192, Japan
}

\begin{abstract}
Many synthetic methods for heteropolyoxovanadates and lacunary polyoxovanadates have been developed in recent years. We outline various approaches used to produce new polyoxovanadate species, including heterometal-incorporated complexes of tetravanadates, hexavanadates, decavanadates and dodecavanadates. In particular, three types of synthetic routes are explored; based on i) coordination of metavanadate species to transition metal cations, ii) oxidation of reduced polyoxovanadates, and iii) template synthesis. Metavanadate species can coordinate to metal cations as inorganic macrocyclic ligands to form heteropolyoxovanadates. The incorporation of a heterometal cation into decavanadates has also been reported. The oxidation reaction of reduced polyoxovanadates provides a new route to the formation of the lacunary polyoxovanadates, which can serve as inorganic host molecules. Dodecavanadates are bowl-type molecules of particular structural interest; a chloride anion can be incorporated into the bowl through a template synthesis. Structural transformations between these dodecavanadate species and alkoxopolyoxovanadates are also described.
\end{abstract}

Keywords: Polyoxovanadates; Lacunary polyoxovanadates; Heteropolyoxovanadates 
* Corresponding author. Tel.: +1 8176264 5695, FAX: +1 81762645742

E-mail address: hayashi@kenroku.kanazawa-u.ac.jp

\section{Contents}

\section{Abstract}

1. Introduction

2. Synthetic procedures

2.1 Nonaqueous chemistry of polyoxovanadates using tetraalkylammonium salts

2.2 General methods for the synthesis of polyoxovanadates

3. Tetravanadate-supported metal complexes

4. Heterometal-incorporated decavanadate frameworks

5. Alkoxohexavanadates

6. Heteropolyoxovanadates

7. Lacunary polyoxovanadates

8. Dodecavanadates

9. Conclusions

10. References 


\section{Introduction}

Decavanadate, $\left[\mathrm{H}_{n} \mathrm{~V}_{10} \mathrm{O}_{28}\right]^{(6-n)-}$, which are the predominant polyoxovanadate species in the acidic $\mathrm{pH}$ range, have recently attracted attention due to their medicinal $[1,2]$ and biochemical behavior [3,4]. Once regarded as pure inorganic compound, decavanadtes have been found to have a role in biological system through equilibrium with labile vanadate species in aqueous solution [5]. The effects of decavanadates in biological systems draw attention due to their potential biological activities [6]. Theoretically, the special cell compartment where vanadium may be accumulated is able to stabilize polyoxovanadates through hydrogen bond formation. The protonation of decavanadates allows them to interact with numerous biological molecules such as proteins through hydrogen bonds [7]. These interactions can result in the fomation of a protective cage in the cell that harbors inorganic decavanadates without decomposition. One example of the use of these interactions is the investigation of reverse micelle environments using decavanadates as a probe of proton gradient in the system [8]. The distribution of decavanadates in the cell may be monitoring using ${ }^{51} \mathrm{~V}$ NMR chemical shifts as a probe [9]. Hydrolytic activity of polyoxovanadates has been studied to model a DNA phosphodiester bond cleavage, and dynamic polyoxovanadate frameworks may allow for the interaction and incorporation of phosphodiester moieties into the polyoxovanadate skeleton [10].

The coordination chemistry of vanadium allows not only for a tetrahedral or an octahedral coordination environment but also for a pyramidal coordination mode with a wide variety of valence states [11]. In contrast, phosphate chemistry only adopts a tetrahedral coordination environment, yet a range of oligomeric complexes may be formed through three types of condensation mode: linear, cyclic or branched modes. It allow these species to serve many biological roles, including the storage of phosphate, a source of energy, and sequestration of multivalent cations [12]. Polyoxovanadates such as decavanadates are also expected to have versatile activities due to their rich coordination chemistry. Further study of polyoxovanadates is required to reveal the stepwise formation mechanism of decavanadates in solution [13].

In highly alkaline conditions, the formation of polyoxo species is difficult, as only orthovanadate $\left[\mathrm{VO}_{4}\right]^{3-}$ is formed. When the solution is acidified, the protonation reaction of the oxido group begins with the formation of $\left[\mathrm{HVO}_{4}\right]^{2-}$, $\left[\mathrm{H}_{2} \mathrm{VO}_{4}\right]^{-}$, and $\mathrm{H}_{3} \mathrm{VO}_{4}$ as 
intermediates. The fully protonated $\mathrm{H}_{3} \mathrm{VO}_{4}$ is suggested to be a minor species and is easily converted to $\left[\mathrm{VO}_{2}\right]^{+}$species with increasing coordination numbers [14]. These protonated species can exist only in dilute solutions. As the solution becomes more acidic, they are soon joined by a few other species; condensation reactions of orthovanadates by elimination of water initiate the formation of various polyoxovanadate species. In the $\mathrm{pH}$ range $8-13$, monovanadates, $\left[\mathrm{HVO}_{4}\right]^{2-}$, divanadates, $\left[\mathrm{V}_{2} \mathrm{O}_{7}\right]^{4-}$, and metavanadates, $\left[\mathrm{VO}_{3}\right]_{n}{ }^{n-}(n=3$ or 4$)$ are particularly stable colorless compounds; divanadates, also known as pyrovanadates, are probably the smallest polyoxovanadate species. ${ }^{51} \mathrm{~V}$ NMR is a powerful method for studying equilibrium in these species, and many studies have been reported: for example, exchange pathways have been investigated through time-resolved ${ }^{51} \mathrm{~V}$ 2D NMR [15]. The mono-, di- and tetravanadates, $\left[\mathrm{VO}_{4}\right]^{3-},\left[\mathrm{V}_{2} \mathrm{O}_{7}\right]^{4-}$, and $\left[\mathrm{V}_{4} \mathrm{O}_{12}\right]^{4-}$ have the same structures as the corresponding phosphates, $\left[\mathrm{PO}_{4}\right]^{3-},\left[\mathrm{P}_{2} \mathrm{O}_{7}\right]^{4-}$, and $\left[\mathrm{P}_{4} \mathrm{O}_{12}\right]^{4-}$. Equilibrium analyses of mixed vanadate-phosphate species have also been investigated [16,17].

Polyoxovanadates larger than the pentameric species, other than decavanadates, have not been found to any great extent in aqueous solution [18]. The equilibrium between metavanadates and decavanadates is slow, and there are certainly other intermediate species that have yet to be discover. The structure of decavanadates show some similarity with other representative polyoxometalate species, such as paramolybdates, upon the removal of two or more octahedra from the ten $\mathrm{VO}_{6}$ units. Decavanadates have multi-protonation sites and the protonated species are in equilibrium with hydrated dioxovanadium salts. These salts contain the dioxo species, $\left[\mathrm{VO}_{2}\left(\mathrm{H}_{2} \mathrm{O}\right)_{4}\right]^{+}$, in which the oxygen is double-bonded [19]. The structure and stability of dioxo cationic species have been investigated in a theoretical study [20]. In a formal sense, polymeric oxides, polyoxovanadates and orthovanadates are linked by a sequence of hydrolysis and condensation reactions (Fig. 1). In this scheme, the cationic species may be formed in further acidic condition but are rather hypothetical because spontaneous hydrolysis leads to the formation of the hydrated dioxovanadium cation, $\left[\mathrm{VO}_{2}\left(\mathrm{H}_{2} \mathrm{O}\right)_{4}\right]^{+}$as the main species in acidic media [21].

Insert Fig. 1.

The structure of decavanadates, which have $D_{2 h}$ symmetry, is closely related to the 
representative polyoxometalates known as Lindqvist-hexamer, $\left[\mathrm{M}_{6} \mathrm{O}_{19}\right]^{n-}$ which have approximately $O_{h}$ symmetry, although the existence of hexavanadate core itself in aqueous solution is not known. It may be too labile to exist as anything but uncertain equilibrated species among the newly aggregated units of dimeric to pentameric species. Some of the details are matters for debate and will doubtless change with future discoveries, but the overall equilibrium in aqueous solution is well-established [22].

Polyoxometalate condensation reaches different stages in different elements. For example, the small, highest oxididation state $\mathrm{Cr}^{\mathrm{VI}}$ exhibits a simple equilibrium between chromate and dichromate, while molybdate and tungstate with their larger ionic radii, can progress further, condensing into larger polyoxometalates. The recent discovery of nanoscale polyoxomolybdates, such as the wheel-shaped or spherical compounds called Keplerates, with more than 100 metal atoms, has transformed polyoxometalate chemistry into an emerging nano-science [23]. The chemistry of vanadate and phosphate complexes inspired Zubieta's group to explore an extensive series of transition metal phosphate-vanadate complexes [24] and organically templated vanadium phosphates [25], utilizing hydrothermal synthesis to obtain a wide variety of inorganic-organic hybrid species in the solid state [26].

Previously, as much of the work in polyoxometalate chemistry remains focused on molybdates and tungstates, few polyoxovanadate frameworks had been crystallographically identified. Today, in contrast, more than a dozen polyoxovanadates have been discovered, with many more yet to be explored. The square pyramidal geometry of the vanadium coordination environment results in a remarkable diversification of structure, including spherical-hosts. New inorganic host-guest spherical molecules have been developed by Müller's group [27]; these are not highlighted in this review. Polyoxovanadate spheres are formed through linkages of multiple square-pyramidal $\left\{\mathrm{VO}_{5}\right\}$ units, with the bottoms of all the pyramids pointing inside the sphere and the guest anion sitting at the center. The interactions between the guest anion and the cationic vanadium centers stabilize the spherical framework. The anionic cages are usually mixed-valence state or a fully reduced state, as seen in $\left[\mathrm{V}_{15} \mathrm{O}_{36}(\mathrm{Cl})\right]^{5-}[28],\left[\mathrm{V}_{18} \mathrm{O}_{42}(\mathrm{X})\right]^{\mathrm{n}-}\left(\mathrm{X}=\mathrm{H}_{2} \mathrm{O}, \mathrm{Cl}^{-}, \mathrm{Br}^{-}, \mathrm{I}^{-}\right)$[29], [ $\left.\mathrm{V}_{22} \mathrm{O}_{54}\left(\mathrm{ClO}_{4}\right)\right]^{7-}$ [30], and $\left[\mathrm{V}_{34} \mathrm{O}_{82}\right]^{10-}[31]$. The addition of transition metal complexes to these reduced core can produce layered solid materials, $\left[\mathrm{V}_{18} \mathrm{O}_{42}(\mathrm{X})\right]\left(\mathrm{X}=\mathrm{H}_{2} \mathrm{O}, \mathrm{Cl}^{-}, \mathrm{Br}^{-}\right)$interlinked by vanadium complexes [32-34]. 
Much of the work highlighted in this review is concerned with synthetic methodologies for polyoxovanadates, beginning with the tetravanadate-supported complexes. This review focuses on reactions induced by metavadate species which provide a variety of novel polyoxovanadate "complexes". We also describe the use of coordination chemistry to obtain heteropolyoxovandates. When a cyclic tetravanadate that is too small to incorporate a metal cation in the ring is used as a ligand, a tetravanadate-supported complex is formed. Furthermore, the tetravanadate can expand to form a larger macrocyclic ring. Transition metal cations acting as heteroatoms can play the role of a Lewis acid, allowing the tetravanadate to expand the chain of its cyclic phosphate-like structure, which permits the condensation of crown-like species to form larger ligands. A metavanadate-based macrocyclic ligand can bind a single heteroatom at the center, and in some cases, it becomes large enough to allow the assembly of a binuclear or tetranuclear cluster unit within the ring. Although some of these approaches are applicable to important areas of research such as hybrid materials, or metal inorganic frameworks, we have limited our review to molecular system which is soluble in organic solution, such as heteropolyoxovanadates and functional polyoxovanadates. A new synthetic method utilizing the redox chemistry of vanadium has been also found to be useful [35]. Reductive reactions using organometallic fragments may help to expand the polyoxovanadate framework. In the course of our experimental survey using redox reactions, we found that oxidation of reduced polyoxovanadate species can form a new spherical polyoxovanadate, $\left[\mathrm{V}_{18} \mathrm{O}_{46}\left(\mathrm{NO}_{3}\right)\right]^{5-}$, which has a chiral double helical structure [36]. Our recent studies in this area are described in this review to demonstrate the synthesis of open spherical molecules, which are known as lacunary heteropolyoxovanadates, with a perspective on the future prospects of such systems.

\section{Synthetic procedures}

Various synthetic methods for polyoxovanadates have been used to build complex molecules while surveying the best equilibrium points with regard to several synthetic parameters, such as concentration, $\mathrm{pH}$, molar ratio, temperature, choice of solvent and counter cation. The exploration of new synthetic routes can be very time-consuming. Materials that do not form crystals with distinct chemical compositions and atoms 
organized in an orderly array of repeating units cannot be identified as polyoxovanadates. For the synthesis of new polyoxovanadate species, the choice of counter cation and condensation method is of crucial importance.

2.1 Nonaqueous chemistry of polyoxovanadates using tetraalkylammonium salts

Synthesis in organic solvents increases the versatility of polyoxovanadate chemistry. The solubility of polyoxovandates in organic solvent may be increased by replacing the counter cation with quaternary ammonium ions. The tetrabutylammonium salts of isopolyoxometalates have been found to be useful starting materials for the synthesis of numerous polyoxometalates in organic solvents. They are often dissolved in a polar aprotic solvent such as acetonitrile, dichloromethane, or nitromethane. The use of such organic solvents prevents the equilibrium from collapsing with the formation of various species. The first efforts to produce polyoxovanadates that were soluble in organic solvents utilized controlled hydrolysis with addition of alkylammonium salts in aqueous solution to produce decavanadate [37,38]. An improved synthetic method for alkylammonium decavanadate complexes was established later [39].

Cation replacement in polyoxovanadates has been reported for a protonated tetravanadate, $\left[\mathrm{HV}_{4} \mathrm{O}_{12}\right]^{3-}$, employing a tetra- $n$-butylammonium cation [40]. The four vanadium atoms have a butterfly-like bent structure, with two oxido groups at the bent position on opposite sides of the chain forming an intramolecular hydrogen bond. The formation of planar $\left[\mathrm{V}_{4} \mathrm{O}_{12}\right]^{4-}$ with tert-butylammonium cation was reported later [41]. A proton-free tetra-n-butylammonium salt was prepared by Yagasaki's group, along with a series of vanadoselenites, $\left[\mathrm{Se}_{x} \mathrm{~V}_{4-x} \mathrm{O}_{12-x}\right]^{(4-x)-}(x=1,2)$ [42]. The structure of the tetraethylammonium salt was confirmed to have a planar configuration, with all four vanadium atoms sitting nearly in the same plane [43], and a water molecule supported on either side of the plane through hydrogen bonds. The trivanadate, $\left[\mathrm{V}_{3} \mathrm{O}_{9}\right]^{3-}$, was also isolated as a tetra- $n$-butylammonium salt [44]. Interestingly, these cyclic tetra- and trivanadate species show two distinct resonances in ${ }^{51} \mathrm{~V}$ NMR spectroscopy, with a temperature-dependent intensity ratio. This suggests the presence of two types of equilibrated species, despite the fact that the cyclic structure suggests that all of the vanadium atoms are chemically equivalent. Plausible explanations discussed in the 
literature include the different ionic pairings, and interaction with water molecules through hydrogen bonds, and another possibility is a slow conformational equilibrium.

${ }^{51} \mathrm{~V}$ NMR studies of protonated tetravanadate reveal the presence of an equilibrium with tri- and pentavanadate species [44].

2.2 General methods for the synthesis of polyoxovanadates

Polyoxovanadates can be obtained by successive condensation and recombination reactions starting from a mononuclear vanadium oxoacid or a precursor such as metavanadate. While the synthetic methods mentioned here allow access to some novel polyoxovanadates, these species tend to equilibrate with thermodynamically stable species such as metavanadates or decavanadates through a series of hydrolysis reaction, or protonation and water elimination reactions. Polyoxovanadates synthesized by nonaqueous methods are generally susceptible to transformation back to the well-established species. For the synthesis of new polyoxovanadates, the use of a nonaqueous solvent is required, and even in such nonaqueous condition, it is essential to control the amount of acid and water present to avoid shifting the equilibrium.

A widely used synthetic pathway for the preparation of polyoxovanadates is based on an acid condensation reaction, which proceeds through protonation of smaller polyoxovanadates. The resulting water elimination reaction decreases the number of oxygen atoms, and the oxygen/vanadium ratio decreases when the condensation product is formed. An example is the synthesis of $\left[\mathrm{V}_{10} \mathrm{O}_{28}\right]^{6-}$ from $\left[\mathrm{VO}_{3}\right]_{n}{ }^{{ }^{-}}$, in which precise control of stoichiometry, acid content, and concentrations is necessary. The formation of decametallic species is easily recognizable due to the resulting yellow color.

To avoid the necessity of exact control of acidity, polyoxovanadates may also be synthesized by hydrolysis of metal alkoxo species. When using this route, no $\mathrm{pH}$ adjustment may be necessary, but a controlled amount of water is added to the alkoxide. The synthesis of $\left(n-\mathrm{Bu}_{4} \mathrm{~N}\right)_{3}\left[\mathrm{H}_{3} \mathrm{~V}_{10} \mathrm{O}_{28}\right]$ has been carried out in this way [37]. To neutralize the resulting proton formation, the addition of extra base is required. Careful handling of air-sensitive alkoxides is required to avoid the unexpected formation of oxoor hydroxo-bridged species. A large quantity of the complex must be used to ensure the reaction takes the correct course; otherwise the reaction may be altered by the presence of 
a small amount of water in the solvent.

The two reactions detailed above, acid condensation and alkoxide hydrolysis, are widely used preparation methods of polyoxovanadates, but an alternative is the use of a redox reaction. Polyoxovanadates have an electrophilic nature, which originates from the presence of $\mathrm{V}^{\mathrm{V}}$ vanadium atoms. In contrast, reduced polyoxovanadates with a uniform valence state $\mathrm{V}^{\mathrm{IV}}$ or a mixed-valence state of $\mathrm{V}^{\mathrm{IV}} / \mathrm{V}^{\mathrm{V}}$ are nucleophilic. Assuming the same framework but a different oxidation state, the reduced form has more nucleophilic character due to a build-up of negative charge on the surface. To promote a condensation reaction, the experimental conditions can be controlled to take advantage of these electrophilic and nucleophilic characteristics. Either reduction of the highest oxidation state polyoxovanadates or the oxidation of reduced polyoxovanadates is employed. Careful adjustment of the stoichiometry of the redox reagents, so that only half of the molecule undergo reduction/oxidation, results in a 1:1 mixture of compounds, in which half of the molecules are the electrophilic polyoxovanadates and the other half are the nucleophilic reduced polyoxovanadates. A condensation reaction then takes place between the $\mathrm{V}^{\mathrm{V}}$ form and the reduced form, driven by a nucleophile-electrophile interaction. The reaction must be carried out under nitrogen to prevent spontaneous reoxidation by atmospheric oxygen; otherwise no coupling reaction is observed. When an appropriate template is chosen, the process may produce a template-encapsulated polyoxovanadate with a spherical shape. The charge balance and structural stabilities with the template determine the size of the condensed polyoxometalates. To adjust the stoichiometry of the reaction and achieve the optimum yield, the addition of an optimized amount of acid is required to promote the dehydration condensation reaction [35].

\section{Tetravanadate-supported metal complexes}

Cyclic tetravanadate, $\left[\mathrm{V}_{4} \mathrm{O}_{12}\right]^{4-}$, is a representative species in nonaqueous solvents. The condensation of four vanadate units result in an accumulation of negative charge, and this confer coordination ability as a multidentate ligand to cationic metals. The three representative coordination modes of tetravanadate are shown in Fig. 2.

Insert Fig. 2. 
The protonated form of the tetravanadate has a bending tetranuclear structure in a butterfly form. This conformation may be regarded as bidentate (Fig. 2(a)), as reported in $\left[\mathrm{Ru}^{\mathrm{II}}\left(\mathrm{C}_{8} \mathrm{H}_{12}\right)\left(\mathrm{CH}_{3} \mathrm{CN}\right)_{2} \mathrm{~V}_{4} \mathrm{O}_{12}\right]^{2-}$ complexes [45].

The reaction with metal cations such as $\left[\mathrm{Zn}^{\mathrm{II}} \mathrm{Cl}\right]^{+}$and $\left[\mathrm{Co}^{\mathrm{II}} \mathrm{Cl}\right]^{+}$resulted in the tetravanadate-supported complexes, $\left[(\mathrm{MCl}) \mathrm{V}_{4} \mathrm{O}_{12}\right]^{3-}\left(\mathrm{M}=\mathrm{Co}^{\mathrm{II}}, \mathrm{Zn}^{\mathrm{II}}\right)$ [46], in which the tetravanadate acts as a tridentate ligand through the coordination of three oxido groups (Fig. 2(b)) to tetrahedral $\mathrm{Zn}^{\mathrm{II}}$ or $\mathrm{Co}^{\mathrm{II}}$. Coordination complexes containing a chloride ligand offer a model of a catalytically active center on the oxide surface. Fluxional behavior of the tetrahedaral metal unit on the surface of the tetravanadate is observed by ${ }^{51} \mathrm{~V}$ and ${ }^{17} \mathrm{O}$ NMR [46].

Syntheses to modify the surface of tetravanadates have been developed, using square planar organometallic complexes such as $\left[\mathrm{Rh}\left(\mathrm{C}_{8} \mathrm{H}_{12}\right)\right]^{+}$and $\left[\operatorname{Ir}\left(\mathrm{C}_{8} \mathrm{H}_{12}\right)\right]^{+}$to give bifunctional $\left[(\mathrm{MR})_{2} \mathrm{~V}_{4} \mathrm{O}_{12}\right]^{2-}$ species [47-49]. The tetravanadate supports one square planar organometallic group on each side of the ring, and with the resulting chelating coordination of two square planar complexes, may be regarded as a tetradentate ligand (Fig. 2 (c)). The characteristic feature of these complexes is the planar conformation of the four vanadium atoms, each with two terminal oxygen atoms. After coordination of the two organometallic groups, four terminal oxygen atoms are available, and "hopping” of the organometallic group between the oxido groups is possible. Variable temperature NMR studies suggest that there is an intramolecular pivoting mechanism for the organometallic groups around the tetravanadate ring (Fig. 3) [50,51]. A tetravanadate-supported palladium complex with $\eta^{3}$-allyl ligands, $\left[\left\{\left(\eta^{3}-\mathrm{C}_{4} \mathrm{H}_{7}\right) \mathrm{Pd}\right\}_{2} \mathrm{~V}_{4} \mathrm{O}_{12}\right]^{2-}$, has also reported in a reductive coupling reaction of polyoxovanadates [52]. The neutral complexes $\left[\left\{\mathrm{M}(\text { phen })_{2}\right\}_{2} \mathrm{~V}_{4} \mathrm{O}_{12}\right]\left(\mathrm{M}=\mathrm{Co}^{\mathrm{II}}, \mathrm{Mn}^{\mathrm{II}}, \mathrm{Ni}^{\mathrm{II}}\right.$ or $\mathrm{Cu}^{\mathrm{II}}$ ) are formed with various coordination modes including a mono-coordinated mode with various divalent coordination complexes [53].

Insert Fig. 3.

These tetravanadate-supported complexes are important models for understanding the catalytic cycle on oxide surfaces. The following key steps are necessary to understand the catalytic mechanism based on these model complexes: i) formation of a 
tetravanadate-supported organometallic complex; ii) migration of the organic groups on the surface; iii) elimination of organic products from the model surface; iv) regeneration of the supported coordination compound with an available coordination site through the presence of a leaving group such as a chloride anion. The tetradentate organometallic complex and the inorganic tridentate complex model steps i) and iv), respectively. Tetravanadate-supported organometallic complexes are further supported on $\mathrm{SiO}_{2}$ to act as a catalyst for the selective oxidation of propene to acetone [54,55]. Similar model complexes involving the tricyclic phosphate, $\left[\mathrm{P}_{3} \mathrm{O}_{9}\right]^{3-}$, have been reported as tridentate ligands for various organometallic compounds [56-59].

\section{Heterometal-incorporated decavanadate frameworks}

Decavanadates, $\left[\mathrm{H}_{n} \mathrm{~V}_{10} \mathrm{O}_{28}\right]^{(6-n)-}$, are polyprotic acids that can interact with each other through hydrogen bonds; the resulting monomeric or dimeric structures may be controlled based on difference in cation size and surface charge [60]. Mono- to tetraprotonated forms have been reported, and an intricate balance of crystal packing results in a variety of possible protonation sites depending on the choice of cation and solvent [61]. To obtain information about differences in the basicity of the surface oxygen atoms, experimental electrostatic potentials on the surface of the non-protonated form were estimated [62]. The crystal packing of decavanadates exhibits four types of distinct interaction pattern, monomers, dimers, and 1D and 2D arrays, through a variety of hydrogen bond interactions $[63,64]$. In aqueous solution, decavanadate species may be in equilibrium with mononuclear species and substitution of some of the vanadium units may be possible. The incorporation of $\mathrm{Te}^{6+}$ has been observed through ${ }^{51} \mathrm{~V}$ and ${ }^{17} \mathrm{O}$ NMR spectroscopy, with the suggested position of the Te atom at the central junction of the decameric structure, where no terminal oxygen atom is available [65]. Decavanadate contains three chemically different vanadium sites (Fig. 4); the metal sites at the central junction correspond to two central $\mathrm{VO}_{6}$ octahedra containing only bridging oxygen atoms, and two types of peripheral vanadium unit containing a $\mathrm{V}=\mathrm{O}$ bond are assembled around the central units. Elucidation of the heteroatom position by X-ray crystallography may be difficult due to disorder over several sites. Although the position of the proton may be located through crystallographic data, the structure of $\left[\mathrm{HTeV}_{9} \mathrm{O}_{28}\right]^{4-}$ has been reported to 
feature disorder over the inversion center [66]. The preparation of a disubstituted species, $\mathrm{Mo}_{2} \mathrm{~V}_{8}$, resulted in the formation of a mixture of positional isomers, as observed from ${ }^{51} \mathrm{~V}$ and ${ }^{17} \mathrm{O}$ NMR [67]. Substitution by tungstates was also studied using 2D NMR techniques [68]. The mono-substituted complex $\left[\mathrm{H}_{2} \mathrm{MoV}_{9} \mathrm{O}_{28}\right]^{3-}$ was synthesized as a mixture of positional isomers of the substituted species [69].

Insert Fig. 4.

The structure of monosubstituted decavanadate without disorder was recently reported in a mono-Pt ${ }^{\mathrm{IV}}$ derivative, $\left[\mathrm{H}_{2} \mathrm{Pt}^{\mathrm{IV}} \mathrm{V}_{9} \mathrm{O}_{28}\right]^{5-}$, although some controversial issues arose in the characterization of the structure [70,71]. Clear distinct ${ }^{51} \mathrm{~V}$ NMR signals, corresponding to specific substitution sites, were observed. While molybdenum-substituted derivatives require separation of the positional isomers in order to identify the exact nature of the individual complexes, this mono-platinum-substituted complex favors placement of the heteroatom at the central position exclusively. The substituted position has no terminal oxo group but all bridging oxido ligands. No high $d$-electron count late-transition-metal-oxo complexes were identified until recently [72]. Such metals are unlikely to be found at peripheral positions due to the required presence of a terminal oxo group, which would be unstable to hydrolysis.

Among niobates, similarly substituted decametalates, $\left[\mathrm{Ti}_{2} \mathrm{Nb}_{8} \mathrm{O}_{28}\right]^{8-}$, have been synthesized, and the disubstituted structure is shown in Fig. 4 [73]. Here, the substituted positions are also at the central junction, reflecting the instability of the $\mathrm{Ti}=\mathrm{O}$ bond. In addition, a series of isostructural $\mathrm{Ti}^{\mathrm{IV}}$-substituted decaniobates, $\left[\mathrm{Nb}_{10} \mathrm{O}_{28}\right]^{6-},\left[\mathrm{TiNb}_{9} \mathrm{O}_{28}\right]^{7-}$, and $\left[\mathrm{Ti}_{2} \mathrm{Nb}_{8} \mathrm{O}_{28}\right]^{8-}$, have been synthesized [74]. Decaniobate ions are more stable than vanadium-based ions and are suitable for the study of isotope exchange experiments using ${ }^{17} \mathrm{O}$ NMR spectroscopy [75]. The isotope exchange rate demonstrates the stabilization of the core by substitution, and there are still unknown pathways involving intermediate decametalate forms.

\section{Alkoxohexavanadates}

The most important polyoxovanadates with octahedral $\mathrm{VO}_{6}$ components are the 
various decavanadate salts, $\left[\mathrm{H}_{n} \mathrm{~V}_{10} \mathrm{O}_{28}\right]^{(6-n)-}$. The unique decameric structure is based on a fused dimer of hexametalates, $\left[\mathrm{M}_{6} \mathrm{O}_{19}\right]^{n-}$. Polyoxometalates often adopt a highly symmetrical Lindqvist hexametalate structure. The Lindqvist anion, generated by condensation of six $\mathrm{MO}_{6}$ octahedra and with approximately $O_{h}$ symmetry, is important in the chemistry of $\mathrm{Mo}^{\mathrm{VI}}, \mathrm{W}^{\mathrm{VI}}, \mathrm{Nb}^{\mathrm{V}}$, and $\mathrm{Ta}^{\mathrm{V}}$. In the decavanadate formation process, hexavanadate is a plausible intermediate species, but it is not observed in aqueous chemistry. In the more stable decaniobates of equivalent structure, mechanistic insights have been obtained by observation of the oxygen isotope exchange rate, and the formation of a metastable intermediate has been suggested based on the relatively facile and reversible exchange of oxygen atoms with water [76]. An interconversion reaction between hexaniobate and decaniobate has also reported, and the proposed mechanism involves a dissociation reaction to tetraniobate from decaniobate (Fig. 5) [77]. A similar mechanism may operate in decavanadates.

Insert Fig. 5.

The structural instability of hexavanadate, $\left[\mathrm{V}_{6}^{\mathrm{V}} \mathrm{O}_{19}\right]^{8-}$, arises from the small ionic radius of $\mathrm{V}^{\mathrm{V}}$ atoms. To stabilize the highly negative core, protection of the nucleophilic surface oxygen atoms is required. The protection by capping groups on the surface oxygen atoms is an effective method: the protecting groups employed are organometallic complexes [78-80] and $\mathrm{V}^{\mathrm{IV}}$ coordination complexes containing alkoxo groups [81]. By using positively charged protecting groups, it is possible to compensate for the high negative charge of the hexavanadate ion.

The substitution of bridging oxygen atoms with alkoxide ligands produces an alkoxohexavanadate core [82]. This serves to diminish the charge, and a reducing state of $\mathrm{V}^{\mathrm{IV}}$ is preferred by the introduction of alkoxide ligands [83]. The substitution of all bridging oxygens with $\mathrm{CH}_{3} \mathrm{O}^{-}[84,85]$ or $\mathrm{C}_{2} \mathrm{H}_{5} \mathrm{O}^{-}[86,87]$ ligands produces neutral hexavanadates, $\left[\mathrm{V}^{\mathrm{IV}}{ }_{4} \mathrm{~V}_{2}{ }_{2} \mathrm{O}_{7}(\mathrm{OR})_{12}\right]$. The magnetic behavior of a series of substituted complexes has been investigated [88] and DFT studies show the $d$ electrons are trapped within the hexavanadate core [89]. The introduction of alkoxide ligands has also been reported in decavanadates forming $\left[\mathrm{V}^{\mathrm{V}}{ }_{10} \mathrm{O}_{26}\left(\mathrm{OCH}_{3}\right)_{2}\right]^{4-}[90]$. Stabilization of the reduced state is observed in the decavanadate complex, $\left[\left(\mathrm{V}^{\mathrm{IV}} \mathrm{O}\right)_{6} \mathrm{O}\left\{\mathrm{EtC}\left(\mathrm{CH}_{2} \mathrm{O}\right)_{3}\right\}_{4}\right]^{2-}$ substituted with triol ligands [91], although polyoxovanadates are generally assumed to have the 
valence state of the highest oxidation state $\mathrm{V}^{\mathrm{V}}$. Alkoxo derivatives are able to stabilize $\mathrm{V}^{\mathrm{III}}$ hexavanadates, $\left[\left(\mathrm{V}^{\mathrm{III}} \mathrm{Cl}\right)_{6} \mathrm{O}\left\{\mathrm{MeC}\left(\mathrm{CH}_{2} \mathrm{O}\right)_{3}\right\}_{4}\right]^{2-}[92,93]$.

Although the capping groups or alkoxides are labile and almost certainly dissociate at some stage in solution, the free form of $\left[\mathrm{V}_{6} \mathrm{O}_{19}\right]^{8-}$ has never been isolated. $A \mathrm{~V}^{\mathrm{V}}$ hexavanadate without a bulky capping group, $\left[\mathrm{V}_{6} \mathrm{O}_{12}\left(\mathrm{OCH}_{3}\right)_{7}\right]^{-}$, was prepared by Hill's group. They employed $\mathrm{CH}_{3} \mathrm{O}^{-}$ligands to form $\mathrm{V}^{\mathrm{V}}$ alkoxohexavanadates and investigated their properties by NMR spectroscopy and electrochemistry [94]. A redox-active bis(pyridyl)-capped hexavanadate may also be prepared from the decavanadate using triol-based ligands. The resulting linear zwitterionic coordination polymer may be tailored to air-based oxidation catalysis for removal of pollutants or decontamination of toxic agents, utilizing the redox-active properties of alkoxopolyoxovanadates [95]. The same method has been applied to the synthesis of hybrid organic-inorganic porphyrin polyoxometalate complexes [96].

Although alkoxides are successfully employed in isolating various hexavanadate frameworks, they are generally highly reactive and extremely susceptible to hydrolysis by trace amounts of water. The synthesis and handling of alkoxides require rigorous anhydrous conditions. The alcoholysis of $1 \mathrm{D}$ metavanadate polymers provide an alternative synthetic pathway for $\mathrm{V}^{\mathrm{V}}$ hexametalates. Metavanadate polymer in the solid state are composed of a $1 \mathrm{D}$ chain of vertex-sharing $\mathrm{VO}_{4}$ tetrahedrons, but tight interactions between counter cations prohibit the alcoholysis reaction. Hydrolysis by hot water may cleave the $1 \mathrm{D}$ chain into soluble fragmented species. A $1 \mathrm{D}\left[\mathrm{V}_{4} \mathrm{O}_{11}\right]^{2-}$ polymer chain that is susceptible to alcoholysis can be prepared by a water elimination reaction from the cyclic tetravanadate $\left[\mathrm{V}_{4} \mathrm{O}_{12}\right]^{4-}$ [97]. By using the hydrophobic triphenyl phosphonium cation, interaction between the chains is avoided, facilitating the alcoholysis reaction. The $\left[\mathrm{V}_{4} \mathrm{O}_{11}\right]^{2-}$ polymer has proved to be a successful precursor for the synthesis of alkoxohexavanadate anions. When compared with a discrete tetravanadate, the $\left[\mathrm{V}_{4} \mathrm{O}_{11}\right]^{2-}$ polymer is more stable, yet it is more reactive toward alcoholysis because it has fewer negative charges. The dissolution of $\left(\mathrm{PPh}_{4}\right)_{2}\left[\mathrm{~V}_{4} \mathrm{O}_{11}\right]$ in methanol readily gives an orange solution, allowing crystal growth of hexamethoxohexavanadate, $\left[\mathrm{V}_{6} \mathrm{O}_{13}\left(\mathrm{OCH}_{3}\right)_{6}\right]^{2-}$ [98]. This straightforward synthesis of alkoxides provides a facile route for further development of polyoxovandate synthesis. The conformation of the methoxy substituents is symmetrical, and the view from the pseudo three-fold axis is shown in Fig. 6. The methoxy groups deviate from the vertical 
layer at the center of the pseudo-three-fold axis by $0.2 \AA$ alternating up and down. Although the ${ }^{51} \mathrm{~V}$ NMR spectrum shows a singlet at $-548 \mathrm{ppm}$, as expected from the symmetry of the anion, the methyl signals in the ${ }^{1} \mathrm{H}$ NMR spectrum exhibit multiple peaks in the region 4.2-4.7 ppm. The different chemical environments of the methyl signals may be attributed to the lability of the alkoxides, including isomerization of the bridging methoxy groups at the core. Electrochemical studies show a quasi-reversible one-electron reduction wave $\left(\mathrm{E}=0.314 \mathrm{~V}\right.$ vs. $\left.\mathrm{Ag}^{+} / \mathrm{Ag}\right)$. This simple $\left[\mathrm{V}_{6} \mathrm{O}_{13}\left(\mathrm{OCH}_{3}\right)_{6}\right]^{2-}$ is a good reaction intermediate for the development of new types of polyoxovanadate.

Insert Fig. 6.

Hydrolysis of the methoxy derivatives may form a protonated form of hexavanadate, but it is easily convert to the different polyoxovanadate core that is unidentified. To determine the reaction mechanism for hexametalate formation, it is useful to investigate the more stable $\mathrm{Nb}^{\mathrm{V}}$ derivatives. The oxygen isotope exchange rates of the Lindqvist hexamer, $\left[\mathrm{M}_{6} \mathrm{O}_{19}\right]^{8-}$, have been investigated for Ta and $\mathrm{Nb}$. Isostructural $\mathrm{Nb}^{\mathrm{V}}$ and $\mathrm{Ta}^{\mathrm{V}}$ Lindqvist ions exhibited interesting differences in reactivity through different mechanisms [99]. The importance of metastable forms of the Lindqvist structure has been revealed through oxygen isotope exchange rate studies [100]. Using a combined approach of ESI-MS and complementary DFT, a formation mechanism for hexametalates is proposed in which a metastable intermediate is formed by consecutive steps, incorporating one metal unit at a time [101].

\section{Heteropolyoxovanadates}

In addition to isopolyoxovanadates, polyoxovanadate chemistry is greately diversified by the incorporation of a heteroatom to form heteropolyoxovanadates. Reported heteropolyoxovanadates include $\quad\left[\mathrm{PV}_{14} \mathrm{O}_{42}\right]^{9-} \quad[102,103], \quad\left[\mathrm{Mn}_{2} \mathrm{~V}_{22} \mathrm{O}_{64}\right]^{10-}$, $\left[\mathrm{Mn}_{3} \mathrm{~V}_{12} \mathrm{O}_{40} \mathrm{H}_{3}\right]^{5-}$ [104], and $\left[\mathrm{MV}_{13} \mathrm{O}_{38}\right]^{7-}\left(\mathrm{M}=\mathrm{Mn}, \mathrm{Ni}, \mathrm{Ln}^{3+}\right)$ [105]. Typical polyoxomolybdates and polyoxotungstates composed of $\mathrm{MO}_{6}$ octahedra, known as Keggin or Dawson-type compounds, have a central role in catalysis as well as wealth of other applications, so it is expected that heterpolyoxovanadates of equivalent structure 
may be similarly useful. Part of the reason for the limited number of discrete heteropolyoxovanadates that have been reported is the instability arises from the smaller size of vanadium atoms and the difficulty of accommodating six oxygen atoms around the small $\mathrm{V}^{\mathrm{V}}$ cation. In contrast, metavanadates containing $\mathrm{VO}_{4}$ units have an attractive coordination ability with less steric hindrance, exhibiting monodentate, bidentate, tridentate, and tetradentate modes of coordination, as we elucidated in an earlier section. There are several possible ring sizes for cyclic metavanadates, parallel to the phosphate chemistry. Ring sizes larger than the pentamer, $\left[\mathrm{V}_{5} \mathrm{O}_{15}\right]^{5-}$, are unknown, but we have found the size of the ring may be expanded by the addition of a heterometal cation; the reaction gives a heteropolyoxovanadate in which the ring size fitted to the cation size in a self-organized fashion as shown in Fig. 7.

\section{Insert Fig. 7.}

The ring sizes of currently known heteropolyoxovanadates include penta-, hexa-, octa-, and decameric rings, and coordination through the oxygen atoms parallels crown ether or calixarene chemistry, without the organic ligands. The macrocyclic heteropolyoxovanadates have no carbon atoms in their anionic framework and represent a new type of all-inorganic coordination chemistry. A similar metallacrown chemistry based on the aggregation of organic ligand complexes into metallacrown-type hosts has been investigated [106]. Anion binding of an Anderson-type crown-shaped polyoxovanadate with organic ligands, $\left[\mathrm{V}_{6} \mathrm{O}_{12}(\mathrm{OH})_{3}\left(\mathrm{O}_{2} \mathrm{CCH}_{2} \mathrm{CH}_{2} \mathrm{NH}_{3}\right)_{3}\left(\mathrm{SO}_{4}\right)\right]^{+}$, has also been reported [107].

The first example of a heteropolyoxovanadate may have been a reduced decavanadate, $\left[\mathrm{V}_{10} \mathrm{O}_{26}\right]^{4-}$. It was not recognized as a hetero-complex because all of its metal atom were vanadium. It was obtained through the reaction of the vanadyl cation with $\mathrm{Cu}^{\mathrm{II}}$ or $\mathrm{Zn}{ }^{\mathrm{II}}$ complexes, and its composition was ill-defined [108]. The correct formula and structure were reported later, [109] and an improved synthesis was developed, and the chemical properties of the reduced decavanadate were investigated [110]. A flesh look at this complex, $\left[\left(\mathrm{V}^{\mathrm{IV}} \mathrm{O}\right)_{2} \mathrm{~V}_{8}{ }_{8} \mathrm{O}_{24}\right]^{4-}$, reveals that the macrocyclic $\left[\mathrm{VO}_{3}\right]_{8}{ }^{8-}$ ligand binds two vanadyl cations, $[\mathrm{V}=\mathrm{O}]^{2+}$, at the center of the molecule to form a divanadyl complex with a cyclic octavanadate ligand (Fig. 8(a)). 
Insert Fig. 8.

In acetonitrile, metavanadate species exist as an equilibrium mixture of tetravanadates that differ in their chain orientation, protonation and sometimes, cyclization number. Upon addition of transition metal cationic salts, the equilibrium is shifted toward the formation of larger cyclic species that can adjust to the size of the cationic species. The reaction between a transition metal cation as a heteroatom, and a polyoxoanion as a ligand, represents a new coordination chemistry of macrocyclic heteropolyoxovanadates. The overall stoichiometry of the reactions is summarized in the following equation:

$$
a\left[\mathrm{VO}_{3}\right]^{-}+b \mathrm{M}^{n+} \rightarrow\left[\mathrm{M}_{b}\left(\mathrm{VO}_{3}\right)_{a}\right]^{(a-n \times b)-}
$$

A palladium complex, $\left[\mathrm{PdV}_{6} \mathrm{O}_{18}\right]^{4-}$, (Fig. 8(c)) is formed when a mixture of $\left\{\left(\mathrm{C}_{2} \mathrm{H}_{5}\right)_{4} \mathrm{~N}\right\}_{4}\left[\mathrm{VO}_{3}\right]_{4}$ and bis(benzonitrile)dichloropalladium(II) with a molar ratio of 6:1 is allowed to react [111]. Structural determination reveals the formation of a complex between $\mathrm{Pd}^{\mathrm{II}}$ and cyclic hexavanadate, $\left[\mathrm{VO}_{3}\right]_{6}{ }^{6-}$, composed of six $\mathrm{VO}_{4}$ units bridged together by vertex-sharing of the oxygen atoms. The hexavanadate ring adopts a boat conformation; two of the six $\mathrm{VO}_{4}$ units at the flag positions are not coordinated to $\mathrm{Pd}^{\mathrm{II}}$ leaving two terminal oxygen atoms per unit, whereas the remaining four $\mathrm{VO}_{4}$ units are coordinated to $\mathrm{Pd}^{\mathrm{II}}$ through an oxygen atom, leaving one terminal oxygen per unit. Variable temperature ${ }^{51} \mathrm{~V}$ NMR studies show no conformational change between boat and chair forms, which suggest the complex is stable over a wide temperature range.

The reaction the macrocyclic $\left[\mathrm{VO}_{3}\right]_{8}{ }^{8-}$ ligand with $\mathrm{Cu}^{\mathrm{II}}$ affords a complex, $\left[\mathrm{Cu}_{2} \mathrm{~V}_{8} \mathrm{O}_{24}\right]^{4-}$ (Fig. 8 (b)), whose structure is similar to that of $\left[\mathrm{V}_{10} \mathrm{O}_{26}\right]^{4-}$ and defined by the same octavanadate ring. The interior of both rings contain two metal cations, two $\mathrm{Cu}^{\mathrm{II}}$ in this compound or two $\left[\mathrm{V}^{\mathrm{IV}} \mathrm{O}\right]^{2+}$ in the reduced decavanadate, and the total charge of -4 in both compounds is attained by the inclusion of two cations within the $\left[\mathrm{VO}_{3}\right]_{8}{ }^{8-}$ ring. However, the symmetry of the copper complex $\left(C_{\mathrm{s}}\right)$ is lower than that of the mixed valence decavanadate $\left(S_{8}\right)$. Distortion in the complex is due to the weak interaction of copper with a bridging oxygen at the fifth coordination site.

The complex with $\mathrm{Mn}^{\mathrm{II}}$ is a ferrocene-like sandwich, $\left[\mathrm{Mn}_{2}\left(\mathrm{~V}_{5} \mathrm{O}_{15}\right)_{2}\right]^{6-}$ (Fig. 8 (e)) with two cyclic pentavanadates sandwiching the edge-sharing octahedral dimanganese units. 
Each ring is coordinated to the manganese unit through four $\mu_{2}-\mathrm{O}$ and one $\mu_{3}-\mathrm{O}$ [112]. EXAFS data obtained in acetonitrile is consistent with the solid-state structure.

The largest decavanadate rings are formed on complexation with $\mathrm{Co}^{\mathrm{II}}$ and $\mathrm{Ni}^{\mathrm{II}}$ complexes. The reaction with $\mathrm{Co}^{\mathrm{II}}$ affords $\left[\mathrm{Co}_{2}\left(\mathrm{OH}_{2}\right)_{2} \mathrm{~V}_{10} \mathrm{O}_{30}\right]^{6-}$, in which the macrocyclic decavanadate ring supports edge-sharing octahedrons with $\mathrm{Co}^{\mathrm{II}}$ centers (Fig. 8 (f)). Each cobalt atom is coordinated by five oxido groups from the decavanadate ligand, and the remaining site is occupied by a coordinated water molecule. The cobalt complex shows reversible chromism based on the amount of water present in the solid state (Fig. 9); exposure of a green-yellow sample to water vapor causes the complex to turn brown, while heating causes the sample to return to its original color in a reversible manner. A water-exposed sample in acetonitrile solution requires complete evaporation in order to return to its original color. The color change is interpreted as being due to flexible binding of the decavanadate ligands, which allow variation in the number of water ligands at the cobalt centers. This complex shows no redox in acetonitrile and no reactivity with dioxygen even at low temperature.

Insert Fig. 9.

A decavanadate macrocycle can incorporate a hydroxide cluster unit to give the tetranickel complex, $\left[\mathrm{Ni}_{4} \mathrm{~V}_{10} \mathrm{O}_{30}(\mathrm{OH})_{2}\left(\mathrm{H}_{2} \mathrm{O}\right)_{6}\right]^{4-}$ (Fig. 8 (g)) as yellow green crystals [111]. The nickel tetramer is composed of a di- $\mu$-hydroxo dinuclear core with two capping nickel aqua complexes. In this ring, two $\mathrm{VO}_{4}$ units at the flag positions are not coordinated to $\mathrm{Ni}^{2+}$, and one of the terminal oxygens oriented toward the center interacts with the $\mu$-hydroxo ligands through hydrogen bonding $(\mathrm{O} \cdots \mathrm{O}=2.813 \AA)$.

The ring sizes of these inorganic complexes correlate well with the total charge on the heterometal units: the higher the total charge on the central unit, the larger the vanadate ring. The positive charge of the cationic heterometal at the center compensates the high negative charge of the larger cyclic polyoxovanadates $\left[\mathrm{VO}_{3}\right]_{n}{ }^{n-}$ which are sufficiently large to include metal cations within the ring. These oxide-based macrocyclic complexes dissolve well in acetonitrile, and can be handled on the bench without anaerobic conditions, but control of molar ratio, concentration, and quality of the $\left[\mathrm{VO}_{3}\right]_{n}{ }^{n-}$ solution must be maintained to prevent the precipitation of hydrolysis products during the synthetic procedure. Similar cyclic heteropolyoxovanadium complexes with reduced 
oxidation states $\left[\mathrm{MV}_{6} \mathrm{O}_{6}\left\{\left(\mathrm{OCH}_{2} \mathrm{CH}_{2}\right)_{2} \mathrm{~N}\left(\mathrm{CH}_{2} \mathrm{CH}_{2} \mathrm{OH}\right)\right\}_{6}\right] \mathrm{X}(\mathrm{M}=\mathrm{Na}, \mathrm{Mg}, \mathrm{Mn}, \mathrm{Fe}, \mathrm{Co}$, $\mathrm{Ni} ; \mathrm{X}=\mathrm{Cl}^{-}, \mathrm{Br}^{-}$) have also been reported [113].

\section{Lacunary polyoxovanadates}

A spherical polyoxovanadates has a similarity in structure of fullerenes. The spherical framework is formed by the condensation of $\mathrm{VO}_{5}$ units to resemble a sheet of vanadium pentoxide, $\mathrm{V}_{2} \mathrm{O}_{5}[114,115]$. The versatility of spherical polyoxovanadates arises from the easy modulation of the core, based on weak $\mathrm{V}-\mathrm{O}$ ionic bonds, which have far less bonding energy than $\mathrm{C}-\mathrm{C}$ bonds. Although fullerenes are electronically neutral, spherical polyoxovanadates have a negative charge, and they always accompanied by an anion which act as a template inside the sphere.

Spherical polyoxovanadates were studied by Müller's group and control of the reaction in the reductive condition is the key to the synthesis of the spherical host molecule [116]. The topology and electrostatic balance of the complex explain the encapsulation of an anionic guest inside spherical anion [117]. In spherical polyoxovanadates, there is no possibility of dissociation of a guest anion without destruction of the cage. The removal of a few $\mathrm{V}=\mathrm{O}$ units from the spherical framework, forming a lacunary polyoxovanadate, is necessary to make the guest anion accessible from the outside. For the synthesis of such an open-cage molecule, the intricate balance of charges on the reduced core must be perturbed. We developed such a synthetic route through the oxidation of reduced polyoxovanadates. The reaction of the reduced decavanadate, $\left[\left(\mathrm{V}^{\mathrm{IV}} \mathrm{O}\right)_{2} \mathrm{~V}_{8}{ }_{8} \mathrm{O}_{24}\right]^{4-}$, with two $\mathrm{F}^{-}$template anions gave the mono-lacunary undecavanadate, $\left[\mathrm{HV}^{\mathrm{V}}{ }_{11} \mathrm{O}_{29} \mathrm{~F}_{2}\right]^{4-}$ [118]. The cluster consists of five $\mathrm{VO}_{5}$ units on the belt layer and two capping layers composed of $\mathrm{V}_{3}$ units which sandwich the belt layer. The structure resembles $\left[\mathrm{H}_{6} \mathrm{~V}_{2}{ }_{2} \mathrm{~V}^{\mathrm{IV}}{ }_{10} \mathrm{O}_{30} \mathrm{~F}_{2}\right]^{6-}$ reported by Müller, although this has the non-lacunary parent framework with a reduced oxidation state [119]. The $\mathrm{V}^{\mathrm{V}}$ spherical framework allows for investigation of the complex in acetonitrile through ${ }^{51} \mathrm{~V}$ NMR spectroscopy, in which distinct signals are observed based on the difference in chemical environment due to the lower symmetry of the mono-lacunary framework.

The incorporation of a $\mathrm{Cl}^{-}$guest anion by oxidation of the reduced decavanadate affords a protonated dodecavanadate, $\left[\mathrm{HV}_{12} \mathrm{O}_{32} \mathrm{Cl}\right]^{4-}$. This complex is regarded as a 
tri-lacunary form (Fig. 10). In both this and previous complex, the proton bridges the lacunary position, which can be estimated based on a bond valence sum calculation. To crystallize these lacunary complexes, the addition of chloroform or dichloromethane is important; the packing molecules fill the space produced by the lacunary units, and the protons of the halogenated solvents point toward the oxido surface of the cluster. ${ }^{51} \mathrm{~V}$ NMR observation shows clear signals corresponding to seven types of chemical environment, and no sign of dynamic behavior has been observed in variable temperature studies. These $\mathrm{V}^{\mathrm{V}}$ lacunary polyoxovanadates have a flexible framework and exhibit structural transformation reactions (Fig. 10). It has been found that the addition of excess $n$ - $\mathrm{Bu}_{4} \mathrm{NF} \cdot 3 \mathrm{H}_{2} \mathrm{O}$ in dichloromethane result in the isolation of $\left[\mathrm{HV}^{\mathrm{V}}{ }_{11} \mathrm{O}_{29} \mathrm{~F}_{2}\right]^{4-}$ [118]. The structural transformation reaction is based on nucleophilic attack by the fluoride anion, and is studied by ${ }^{51} \mathrm{~V}$ NMR spectroscopy.

Insert Fig. 10.

\section{Dodecavanadates}

The bowl-type dodecavanadate $\left[\mathrm{V}_{12} \mathrm{O}_{32}\left(\mathrm{CH}_{3} \mathrm{CN}\right)\right]^{4-}$ has an open end from which an acetonitrile molecule is free to dissociate [120]. This host molecules have been reported with several different guest groups, [121,122] and host-guest interactions have been the subject of attention due to the binding preference of the nitrile group, which orients the negative nitrile group inside the negatively charged cage [123,124]. An improved synthesis of $\left[\mathrm{V}_{12} \mathrm{O}_{32}\left(\mathrm{CH}_{3} \mathrm{CN}\right)\right]^{4-}$ by oxidation of a reduced decavanadate $\left[\left(\mathrm{V}^{\mathrm{IV}} \mathrm{O}\right)_{2} \mathrm{~V}_{8}{ }_{8} \mathrm{O}_{24}\right]^{4-}$ has been reported [114]. The bowl-type cage may be regarded as a lacunary-type polyoxovanadate with a corresponding spherical parent framework. The negatively charged cage prohibits the approach of a chloride anion to bind inside the cage, and the direct addition of chloride anions did not result in indication of incorporated products. However, weak interactions with the twelve $\mathrm{V}^{\mathrm{V}}$ centers allow the inclusion of an electron-rich nitrile group, evidenced by reports of acetonitrile-incorporated host-guest complexes. A ship-in-a-bottle type synthesis provides a way to prepare a chloride-incorporated dodecavanadate, $\left[\mathrm{V}_{12} \mathrm{O}_{32}(\mathrm{Cl})\right]^{5-}$. The rim of the bowl molecule 
consists of eight pyramidal vanadium units, and a disk-shaped heteropolyoxovanadate with an octameric macrocyclic polyoxovanadate can be utilized as a scaffold for synthesis. From dicopper heteropolyoxovanadate, $\left[\mathrm{Cu}_{2} \mathrm{~V}_{8} \mathrm{O}_{24}\right]^{4-}$, which is a macrocyclic octavanadate complex, the copper templates are removed using hydrogen cyanide, and subsequent addition of chloride anion yields the chloride incorporated dodecavanadate (Fig. 11) [125].

Insert Fig. 11.

Interestingly the chloride anion of $\left[\mathrm{V}_{12} \mathrm{O}_{32}(\mathrm{Cl})\right]^{5-}$ is tightly trapped inside the cage despite the open framework at room temperature. The stabilization of the anion inside an anion cage is due to a Coulombic interaction between the chloride anion and the $\mathrm{V}^{\mathrm{V}}$ centers. Slow dissociation of the chloride anion is observed at the reflux temperature in acetonitrile, and irreversible dissociation gives acetonitrile-incorporated dodecavanadate. The structural versatility of open-cage molecules means that they can be tailored to provide site-specific reaction fields for molecules capable of residing inside the anionic cage.

\section{Conclusions}

Synthetic studies of heteropolyoxovanadates and lacunary polyoxovanadates have allowed us to gain insight into template effects in the formation of disk-shaped and spherical polyoxovanadates. The chemistry between cyclic metavanadates and heterometal cations defines a new class of heteropolyoxometalates. The heteropolyoxovanadate synthesis approach holds considerable promise with regard to the assembly of disk-shaped macrocyclic complexes with a robust oxide framework but without organic ligands. The synthetic and chemical flexibility of lacunary polyoxovandates allow for tuning of the metal composition and spherical shape for host-guest interactions. Furthermore, disk-shaped inorganic complexes can be utilized as a scaffold for synthesis of bowl-type dodecavanadate, and alkoxohexavanadates is a good precursor for the synthesis of the host molecule. 


\section{References}

[1] M. Aureliano, Dalton Trans. 42 (2009) 9093-9100.

[2] A. Gorzsás, I. Andersson, L. Pettersson, Eur. J. Inorg. Chem. 18 (2006) 3559-3565.

[3] M. Aureliano, D. C. Crans, J. Inorg. Biochem. 103 (2009) 536-546.

[4] D. C. Crans, J. Smee, E. Gaidamauskas, L. Yang, Chem. Rev. 104 (2004) 849-902.

[5] L. Pettersson, I. Andersson, A. Gorzsas, Cood. Chem. Rev. 237 (2003) 77-87.

[6] M. Aureliano (Ed.), Vanadium Biochemistry, Research Signpost, Kerala, India, 2007.

[7] M. Farahbakhsh, H. Schmidt, D. Rehder, Chem. Ber. /Recueil, 130 (1997) 1123-1127.

[8] M. A. Sedgwick, D. C. Crans, N. E. Levinger, Langmuir, 25 (2009) 5496-5503.

[9] D. C. Crans, B. Baruah, A. Ross, N. E. Levinger, Coord. Chem. Rev. 253 (2009) 2178-2185.

[10] N. Steens, A. M. Ramadan, G. Absillis, T. N. Parac-Vogt, Dalton Trans, 39 (2010) 585-592.

[11] D. Rehder, Bioinorganic Vanadium Chemistry (Inorganic Chemistry: A Textbook Series), Wiley Publishers, New York, 2008.

[12] S. J. Omelon, M. D. Grynpas, Chem. Rev. 108 (2008) 4694-4715.

[13] I. Andersson, L. Pettersson, J. J. Hastings, O. W. Howarth, J. Chem. Soc., Dalton Trans, 16 (1996) 3357-3361.

[14] J. J. Cruywagen, J. Bernard, B. Heyns, A. N. Westra, Inorg. Chem. 35 (1996) 1556-1559.

[15] D. C. Crans, C. D. Rithner, L. A. Theisen, J. Am. Chem. Soc. 112 (1990) 2901-2908.

[16] A. Selling, I. Andersson, L. Pettersson, C. M. Schramm, S. L. Downey, J. H. Grate, Inorg. Chem. 33 (1994) 3141-3150.

[17] I. Andersson, A. Gorzsás, C. Kerezsi, I. Tóth, L. Pettersson, Dalton Trans. 22 (2005) 3658-3666.

[18] K. Elvingson, A. G. Baró, L. Pettersson, Inorg. Chem. 35 (1996) 3388-3393.

[19] H. T. Evans, Inorg. Chem. 5 (1966) 967-977.

[20] A. Sadoc, S. Messaoudi, E. Furet, R. Gautier, E. L. Fur, L. le Polles, J. Y. Pivan, Inorg. Chem. 46 (2007) 4835-4843.

[21] M. T. Pope, Heteropoly and Isopoly Oxometalates, Springer-Verlag, Berlin, Heidelberg, 1983.

[22] M. T. Pope, in G. Wilkinson(Ed.), Comprehensive Inorganic Chemistry Volume 3, 
Pergamon Press, 1986, p.1025.

[23] P. Gouzerh, M. Che, L’Actualité Chimique, 298 (2006) 9-22.

[24] R. C. Finn, J. Zubieta, R. C. Haushalter, Prog. Inorg. Chem. 56 (2003) 421-601.

[25] W. Ouellette, G. Wang, H. Liu, G. T. Yee, C. J. O’Connor, J. Zubieta, Inorg. Chem. 48 (2009) 953-963.

[26] M. I. Khan, R. C. Nome, S. Deb, J. H. McNeely, B. Cage, R. J. Doedens, Cryst. Growth Des. 9 (2009) 2848-2852.

[27] A. Müller, H. Reuter, S. Dillinger, Angew. Chem., Int. Ed. Engl. 34 (1995) 2328-2361.

[28] A. Müller, E. Krickemeyer, M. Penk, H.-J. Walberg, H.Bögge, Angew. Chem., Int. Ed. Engl. 26 (1987) 1045-1046.

[29] A. Müller, R. Sessoli, E. Krickemeyer, H. Bögge, J. Meyer, D. Gatteschi, L. Pardi, J. Westphal, K. Hovemeier, R. Rohlfing, J. Döring, F. Hellweg, C. Beugholt, M. Schmidtmann, Inorg. Chem. 36 (1997) 5239-5250.

[30] A. Müller, E. Krickemeyer, M. Penk, R. Rohlfing, A. Armatage, and H. Bögge, Angew. Chem., Int. Ed. Engl. 30 (1991) 1674-1677.

[31] A. Müller, R. Rohlfing, J. Döring, and M. Penk, Angew. Chem., Int. Ed. Engl. 30 (1991) 588-590.

[32] M. I. Khan, E. Yohannes, R. J. Doedens, Angew. Chem. Int. Ed. 38 (1999) 1292-1294.

[33] M. I. Khan, E. Yohannes, D. Powell, Chem. Commun, (1999) 23-24.

[34] M. I. Khan, E. Yohannes, R. J. Doedens, Inorg. Chem. 42 (2003) 3125-3129.

[35] Y. Hayashi, T. Shinguchi, T. Kurata, K. Isobe, ACS Symp. Ser., 974 (2007) 408-423.

[36] Y. Hayashi, Y. Koyama, T. Shinguchi, K. Isobe, Vanadium Biochemistry, Research Signpost, Kerala, (2007) 15-32.

[37] K. F. Jahr, J. Fuchs, R. Oberhauser, Chem. Ber, 101 (1968) 482-486.

[38] J. Fuches, K. F. Jahr, Z. Naturforsch. Teil B, 23 (1968) 1380.

[39] W. G. Klemperer, Inorg. Synth. 27 (1990) 71-85.

[40] J. Fuchs, S. Mahjour, J. Pickardt, Angew. Chem. Int. Ed. Engl. 15 (1976) 374-375.

[41] P. Román, A. S. José, A. Luque, J. M. Gutiérrez-Zorrilla, Inorg. Chem. 32 (1993) 775-776.

[42] H. Nakano, T. Ozeki, A. Yagasaki, Inorg. Chem. 40 (2001) 1816-1819.

[43] H. Nakano, T. Ozeki, A. Yagasaki, Acta Cryst. C58 (2002) m464-m465. 
[44] E. H. Hamilton, P. E. Fanwick, J. J. Wilker, J. Am. Chem. Soc. 124 (2002) 78-82.

[45] D. Attanasio, F. Bachechi, L. Suber, J. Chem. Soc., Dalton Trans. 15 (1993) 2373-2378.

[46] T. Kurata, Y. Hayashi, K. Isobe, Chem. Lett. 38 (2009) 218-219.

[47] V. W. Day, W. G. Klemperer, A. Yagasaki, Chem. Lett, 19 (1990) 1267-1270.

[48] H. Akashi, K. Isobe, Y. Ozawa, A. Yagasaki, J. Cluster Sci. 2 (1991) 291-296.

[49] M. Abe, K. Isobe, K. Kida, A. Nagasawa, A. Yagasaki, J. Cluster Sci. 7 (1996) 103-107.

[50] M. Abe, K. Isobe, K. Kida, A. Nagasawa, A. Yagasaki, J. Cluster Sci. 5 (1994) 565-571.

[51] M. Abe, K. Isobe, K. Kida, A. Yagasaki, Inorg. Chem. 35 (1996) 5114-5115.

[52] Y. Hayashi, N. Miyakoshi, T. Shinguchi, A. Uehara, Chem. Lett. 29 (2000) 170-171.

[53] V. Paredes-García, S. Gaune, M. Saldías, M. T. Garland, R. Baggio, A. Vega, M.

Salah, El Fallah, A. Escuer, E. Le Fur, D. Venegas-Yazigi, E. Spodine, Inorg. Chem. Acta 361 (2008) 3681-3689.

[54] K. Takahashi, M. Yamaguchi, T. Shido, H. Ohtani, K. Isobe, M. Ichikawa, J. Chem. Soc., Chem. Commun, 12 (1995) 1301-1303.

[55] M. Ichikawa, W. Pan, Y. Imada, M. Yamaguchi, K. Isobe, T. Shido, J. Mol. Cat. A: Chemical 107 (1996) 23-38.

[56] V. W. Day, W. G. Klemperer, S. P. Lockledge, D. J. Main, J. Am. Chem. Soc, 112 (1990) 2033-2034.

[57] V. W. Day, W. G. Klemperer, D. J. Main, Inorg. Chem. 29 (1990) 2345-2355.

[58] W. G. Klemperer, D. J. Main, Inorg. Chem. 29 (1990) 2355-2360.

[59] V. W. Day, T. A. Eberspacher, W. G. Klemperer, R. P. Planalp, P. W. Schiller, A. Yagasaki, B. Zhong, Inorg. Chem. 32 (1993) 1629-1637.

[60] S. Nakamura, T. Ozeki, Dalton Trans. 44 (2008) 6135-6140.

[61] S. Nakamura, T. Ozeki, J. Chem. Soc., Dalton, Trans. 4 (2001) 472-480.

[62] N. Bosnjakovic-Pavlovic, A Spasojevic-de Biré, I. Tomaz, N. Bouhmaida, F. Avecilla, U. B. Mioc, J. C. Pessoa, N. E. Ghermani, Inorg. Chem. 48 (2009) 9742-9753.

[63] J. L. Ferreira da Silva, M. F. Minas da Piedade, M. T. Duarte, Inorg. Chem. Acta, 356, (2003) 222-242.

[64] F. Avecilla, Vanadium Biochemistry, Research Signpost, Kerala, India, (2007), 33-43. 
[65] R. I. Maksimovskaya, V. M. Bondareva, G. I. Aleshina, Eur. J. Inorg. Chem. 31 (2008) 4906-4914.

[66] S. Konaka, Y. Ozawa, A. Yagasaki, Inorg. Chem. Commun. 11 (2008) 1267-1269.

[67] R. I. Maksimovskaya, N. N. Chumachenko, Polyhedron, 6 (1987) 1813-1821.

[68] O. W. Howarth, L. Pettersson, I. Andersson, J. Chem. Soc., Dalton Trans. 10 (1989) 1915-1923.

[69] N. Strukan, M. Cindric, B. Kamenar, Polyhedron, 16, (1997) 629-634.

[70] U. Lee, H. -C. Joo, K. -M. Park, S. S. Mal, U. Kortz, B. Keita, L. Nadjo, Angew. Chem. Int. Ed. 47 (2008) 793-796.

[71] R. Cao, T. M. Anderson, D. A. Hillesheim, P. Kögerler, K. I. Hardcastle, C. L. Hill, Angew. Chem. Int. Ed. 47 (2008) 9380-9382,

[72] T. M. Anderson, R. Cao, E. Slonkina, B. Hedman, K. Hodgson, K. I. Hardcastle, W. A. Neiwert, S. Wu, M. L. Kirk, S. Knottenbelt, E. C. Depperman, B. Keita, L. Nadjo, D. G. Musaev, K. Morokuma, C. L. Hill, J. Am. Chem. Soc. 127 (2005) 11948-11949.

[73] M. Nyman, L. J. Criscenti, F. Bonhomme, M. A. Rodriguez, R. T. Cygan, J. Solid State Chem. 176 (2003) 111-119.

[74] C. A. Ohlin, E. M. Villa, J. C. Fettinger, W. H. Casey, Dalton Trans. 15 (2009) 2677-2678.

[75] E. M. Villa, C. A. Ohlin, W. H. Casey, J. Am. Chem. Soc. 132 (2010) 5264-5272.

[76] E. M. Villa, C. A. Ohlin, E Balogh, T. M. Anderson, M. D. Nyman, W. H. Casey, Angew. Chem. Int. Ed. 47 (2008) 4844-4846.

[77] E. M. Villa, C. A. Ohlin, J. R. Rustad, W. H. Casey, J. Am. Chem. Soc. 131 (2009) 16488-16492.

[78] Y. Hayashi, Y. Ozawa, K. Isobe, Chem. Lett. 18 (1989) 425-426.

[79] H. K. Chae, W. G. Klemperer, V. W. Day, Inorg. Chem. 28 (1989) 1423-1424.

[80] Y. Hayashi, Y. Ozawa, K. Isobe, Inorg. Chem. 30 (1991) 1025-1033.

[81] M. Piepenbrink, M. U. Triller, N. H. J. Gorman, B. Krebs, Angew. Chem. Int. Ed. 41 (2002) 2523-2525.

[82] Q. Chen, J. Zubieta, Inorg. Chem. Acta, 198-200 (1992) 95-110.

[83] Q. Chen, D. P. Goshorn, C. P. Scholes, X. Tan, J. Zubieta, J. Am. Chem. Soc. 114 (1992) 4667-4681.

[84] J. Spandl, C. Daniel, I. Brüdgam, H. Hartl, Angew. Chem. Int. Ed. 42 (2003) 1163-1166. 
[85] C. Daniel, H. Hartl, J. Am. Chem. Soc. 127 (2005) 13978-13987.

[86] V. G. Kessler, G. A. Seisenbaeva, Inorg. Chem. Commun. 3 (2000) 203-204.

[87] M. A. Augustyniak-Jablokow, C. Daniel, H. Hartl, J. Spandl, Y. V. Yablokov, Inorg. Chem. 47 (2008) 322-332.

[88] C. Daniel, H. hartl, J. Am. Chem. Soc. 131 (2009) 5101-5114.

[89] E. M. Zueva, S. A. Borshch, M. M. Petrova, H. Chermette, A. M. Kuznetsov, Eur. J. Inorg. Chem. 27 (2007) 4317-4325.

[90] F. Sun, Y-T. Li, Z-Y. Wu, D-Q. Wang, J-M. Dou, Acta Cryst. C62 (2006) m60-m62.

[91] M. I. Khan, Q. Chen, D. P. Goshorn, J. Zubieta, Inorg. Chem. 32 (1993) 672-680.

[92] L. J. Batchelor, R. Shaw, S. J. Markey, M. Helliwell, E. J. L. McInnes, Chem. Eur. J. 16 (2010) 5554-5557.

[93] C. Aronica, G. Chastanet, E. Zueva, S. A. Borshch, J. M. Clemente-Juan, D. Luneau, J. Am. Chem. Soc. 130 (2008) 2365-2371.

[94] D. Hou, G. Kim, K. S. Hagen, C. L. Hill, Inorg. Chem. Acta 211 (1993) 127-130.

[95] J. W. Han, K. I. Hardcastle, C. L. Hill, Eur. J. Inorg. Chem. 13 (2006) 2598-2603.

[96] C. Allain, S. Favette, L-M. Chamoreau, J. Vaissermann, L. Ruhlmann, B. Hasenknopf, Eur. J. Inorg. Chem. 22 (2008) 3433-3441.

[97] S. Sharma, A. Ramanan, P. Y. Zavalij, M. S. Whittingham. Cryst. Eng. Commun. 4 (2002) 601-604.

[98] K. Domae, D. Uchimura, Y. Koyama, S. Inami, Y. Hayashi, K. Isobe, H. Kameda, T. Shimoda, Pure Appl. Chem. 81 (2009) 1323-1330.

[99] E. Balogh, T. M. Anderson, J. R. Rustad, M. Nyman, W. H. Casey, Inorg. Chem. 46 (2007) 7032-7039.

[100] J. R. Black, M. Nyman, W. H. Casey, J. Am. Chem. Soc. 128 (2006) 14712-14720. [101] L. Vilá-Nadal, A. Rodríguez-Fortea, L-K. Yan, E. F. Wilson, L. Cronin, J. M. Poblet, Angew. Chem. Int. Ed. 48 (2009) 5452-5456.

[102] R. Kato, A. Kobayashi, Y. Sasaki, J. Am. Chem. Soc. 102 (1980) 6571-6572.

[103] R. Kato, A. Kobayashi, Y. Sasaki, Inorg. Chem. 21 (1982) 240-246.

[104] H. Ichida, K. Nagai, Y. Sasaki, M. T. Pope, J. Am. Chem. Soc. 111 (1989) 586-591. [105] S. Liu, D. Li, L. Xie, H. Cheng, X. Zhao, Z. Su, Inorg. Chem. 45 (2006) 8036-8040. [106] V. L. Pecoraro, J. Stemmler, B. R. Gibney, J. J. Bodwin, H. Wang, J. W. Kampf, A. Barwinski, Prog. Inorg. Chem. 45 (1997) 83-177.

[107] C. H. Ng, C. W. Lim, S. G. Teoh, H-K. Fun, A. Usman, S. W. Ng, Inorg. Chem. 41 
(2002) 2-3.

[108] C. Heitner-Wirguin, J. Selbin, J. Inorg. Nucl. Chem. 30 (1968) 3181-3188.

[109] A. Bino, S. Cohen, C. Heitner-Wirguin, Inorg. Chem. 21 (1982) 429-431.

[110] S. M. Baxter, P. T. Wolczanski, Inorg. Chem. 28 (1989) 3263-3264.

[111] T. Kurata, A. Uehara, Y. Hayashi, K. Isobe, Inorg. Chem. 44 (2005) 2524-2530.

[112] S. Inami, M. Nishio, Y. Hayashi, K. Isobe, H. Kameda, T. Shimoda, Eur. J. Inorg. Chem. 34 (2009) 5253-5258.

[113] M. I. Khan, S. Tabussum, R. J. Doedens, V. O. Golub, C. J. O’Connor, Inorg. Chem. 43, (2004) 5850-5859.

[114] P. Y. Zavalij, M. S. Whittingham, Acta. Cryst. B55 (1999) 627-663.

[115] J. Livage, Coord. Chem. Rev. 178-180 (1998) 999-1018.

[116] A. Müller, F. Peters, M. T. Pope, D. Gatteschi, Chem. Rev. 98 (1998) 239-271.

[117] A. Müller, H. Reuter, S. Dillinger, Angew. Chem. Int. Ed. Engl. 34 (1995) 2328-2361.

[118] K. Okaya, T. Kobayashi, Y. Koyama, Y. Hayashi, K. Isobe, Eur. J. Inorg. Chem. 34 (2009) 5156-5163.

[119] A. Müller, R. Rohlfing, E. Krickemeyer, H. Bögge, Angew. Chem. Int. Ed. Engl. 32 (1993) 909-912.

[120] W. G. Klemperer, O. M. Yaghi, J. Am. Chem. Soc. 111 (1989) 5959-5961.

[121] W. G. Klemperer, T. A. Marquart, O. M. Yaghi, Mater. Chem. Phys. 29 (1991) 97-104.

[122] N. Kawanami, T. Ozeki, A. Yagasaki, J. Am. Chem. Soc. 122 (2000) 1239-1240.

[123] M. -M. Rohmer, J. Devémy, R. Wiest, M. Bénard, J. Am. Chem. Soc. 118 (1996) 13007-13014.

[124] M. -M. Rohmer, M. Bénard, J. Am. Chem. Soc. 116 (1994) 6959-6960.

[125] T. Kurata, Y. Hayashi, K. Isobe, Chem. Lett. 39 (2010) 708-709. 


\section{Figure Captions}

Fig. 1. The formal hydrolysis sequence of anions and oxides in vanadium(V) chemistry. Even in an extremely acidic medium, the hypothetical $\left[\mathrm{V}\left(\mathrm{OH}_{2}\right)_{6}\right]^{5+}$ species is not observed. The main species observed under strong acidic conditions is cis-dioxo $\left[\mathrm{VO}_{2}\left(\mathrm{OH}_{2}\right)_{4}\right]^{+}$.

Fig. 2. The three representative coordination modes of the cyclic tetravanadate.

Fig. 3. The concerted pivoting mechanism of the tetravanadate-supported organometallic complexes.

Fig. 4. Polyhedral representation of the disubstituted decavanadate structure. The shaded octahedra show $\mathrm{VO}_{6}$ units. The filled circles represent the substituted heteroatoms at the central junction. The open circles represent oxygen atoms.

Fig. 5. Hypothetical mechanism of decametalate transformation. The base-promoted dissociation of the tetrameric fragment may lead to the formation of a hexametalate unit.

Fig. 6. The reaction pathway to the alkoxohexavanadate. The coordinatively unsaturated $1 \mathrm{D}\left(\mathrm{PPh}_{4}\right)_{2}\left[\mathrm{~V}_{4} \mathrm{O}_{11}\right]$ undergoes facile alcoholysis to give symmetrically substituted hexamethoxo-hexavanadate. Yellow, red, and black octants are vanadium, oxygen and carbon atoms, respectively.

Fig. 7. The reaction scheme for the formation of a palladium complex. The template effect of a metal cation expands the ring size of the tetravanadate to form a disk-shaped all-inorganic coordination complex.

Fig. 8. The various all-inorganic macrocyclic complexes as heteropolyoxovanadates.

Fig. 9. The cobalt complex, $\left[\mathrm{Co}_{2}\left(\mathrm{H}_{2} \mathrm{O}\right)_{2} \mathrm{~V}_{10} \mathrm{O}_{30}\right]^{6-}$, shows chromism between green and brown. It is deep green when dry and brown when moist. After exposure to water vapor, the color is restored by heating the sample. In acetonitrile solution, complete evaporation 
is necessary to restore the original color. The addition of alcohol also results in a brown color.

Fig. 10. Synthesis of lacunary polyoxovanadates from the reduced decavanadate:

$\left[\mathrm{HV}^{\mathrm{V}}{ }_{11} \mathrm{O}_{29} \mathrm{~F}_{2}\right]^{4-}$ and $\left[\mathrm{HV}_{12} \mathrm{O}_{32} \mathrm{Cl}\right]^{4-}$. The yellow tetrahedrons represent $\mathrm{VO}_{4}$ units. The blue frames of empty pyramids represent the lacunary units.

Fig. 11. Template switching reaction from a cation to an anion template for bowl type polyoxovanadate synthesis. 


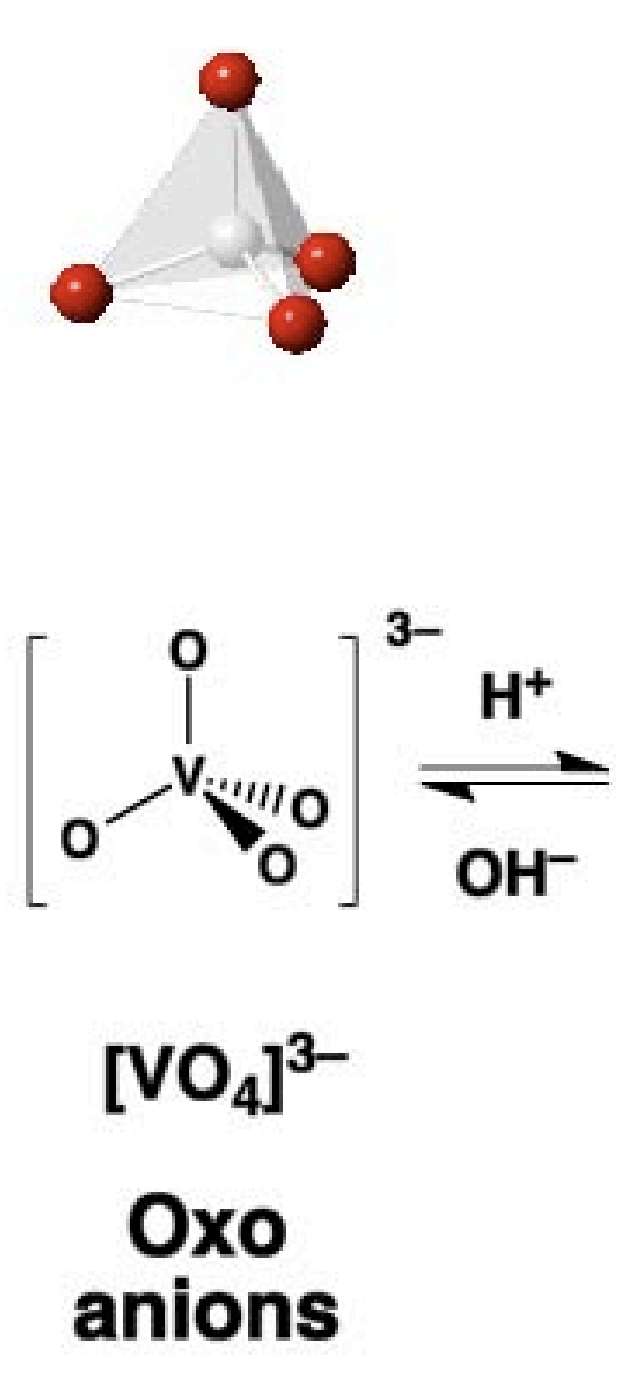

$\mathrm{M} /$ oxo ratio $\mathrm{M}: \mathrm{O}=1: 4$
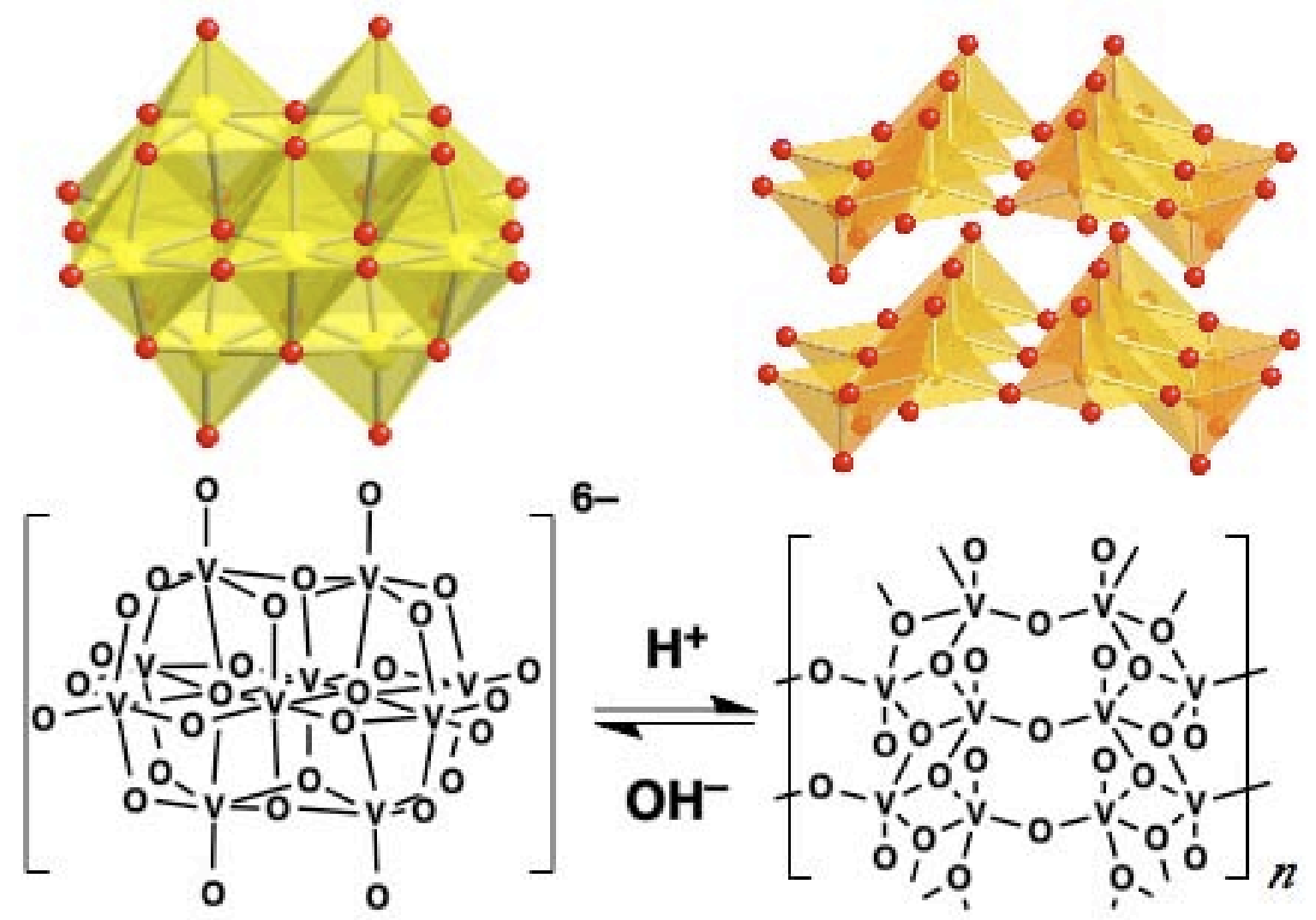

$\left[\mathrm{V}_{10} \mathrm{O}_{28}\right]^{6-}$

Polyoxo anions
$\mathrm{V}_{2} \mathrm{O}_{5}$

Oxide

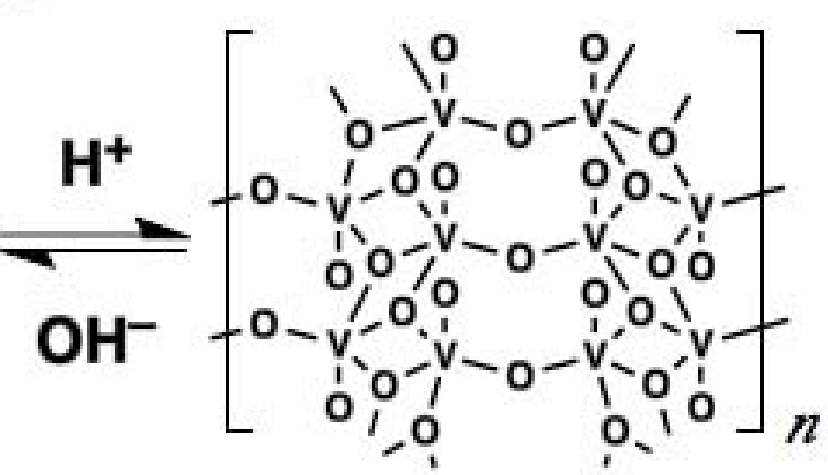

$M: O=1: 2.8$

Water Elimination

Condensation

Hydrolysis

Basic 

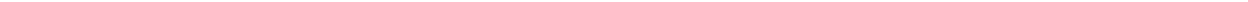


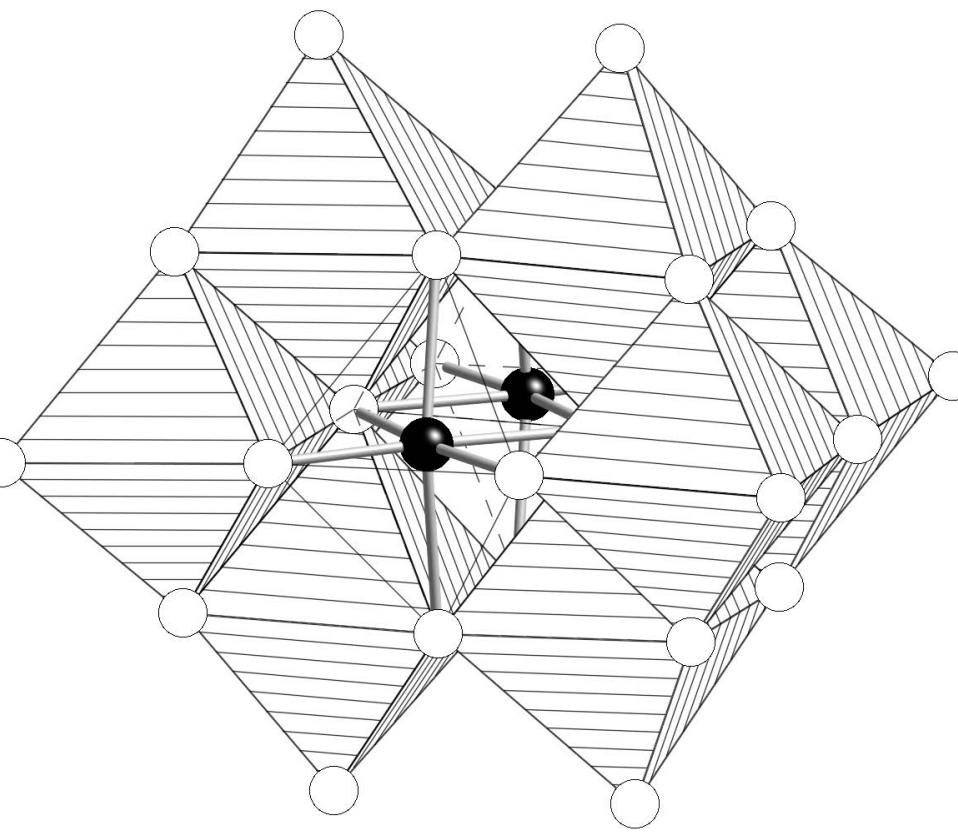



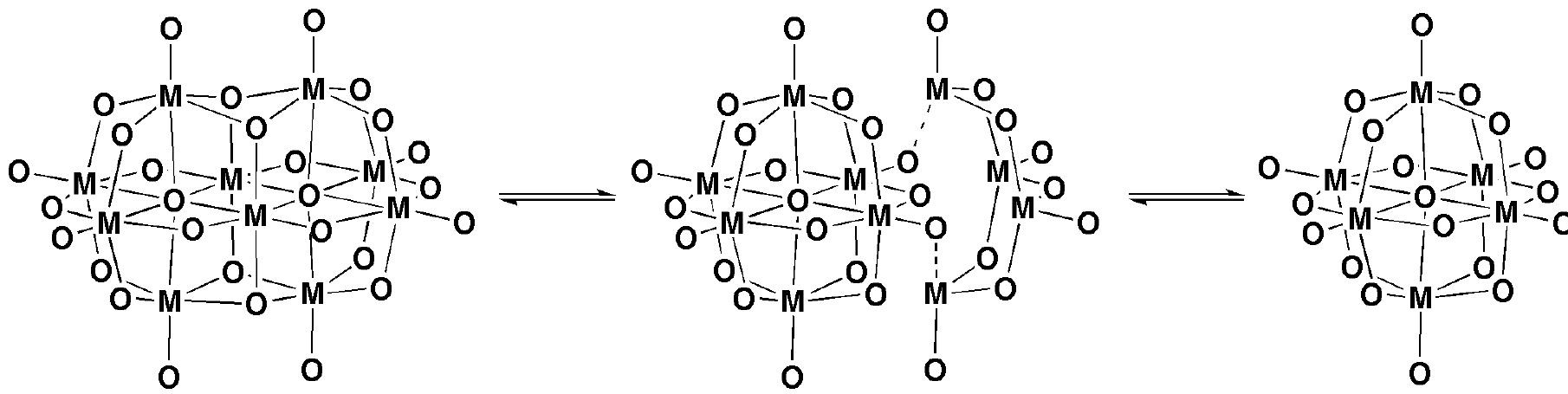


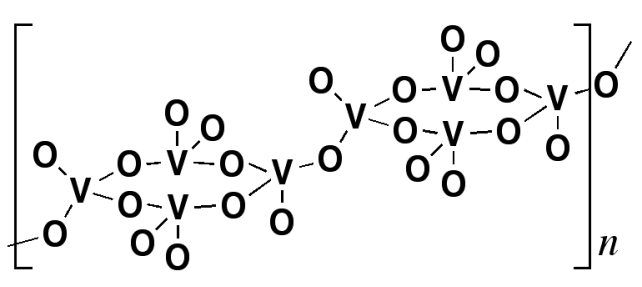

$\mathrm{CH}_{3} \mathrm{OH}$

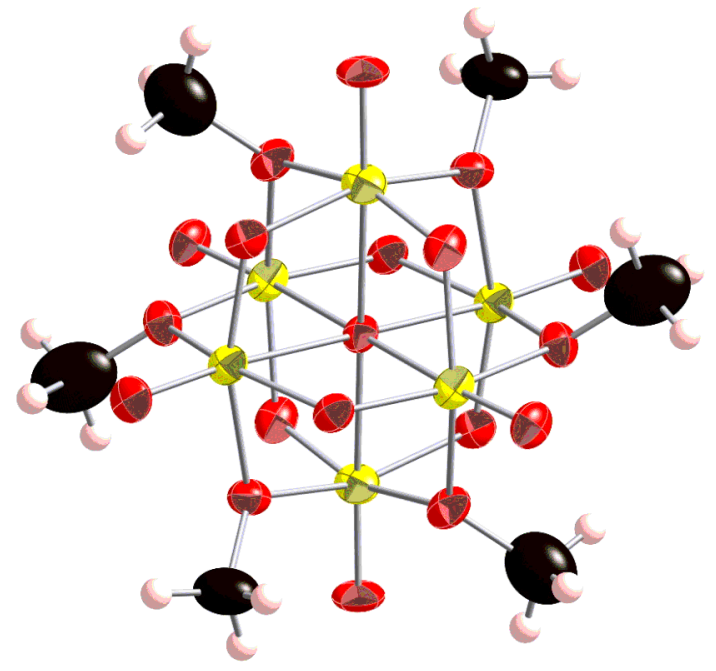


$\left[\mathrm{VO}_{3}\right]_{\mathrm{n}}{ }^{\mathrm{n}-}$

$\mathrm{Pd}^{2+}$

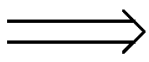

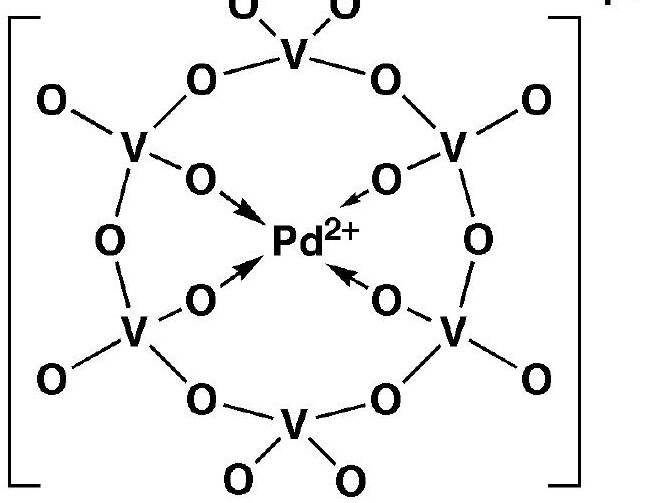




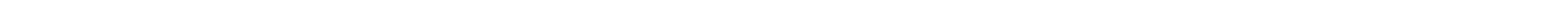


In solid state

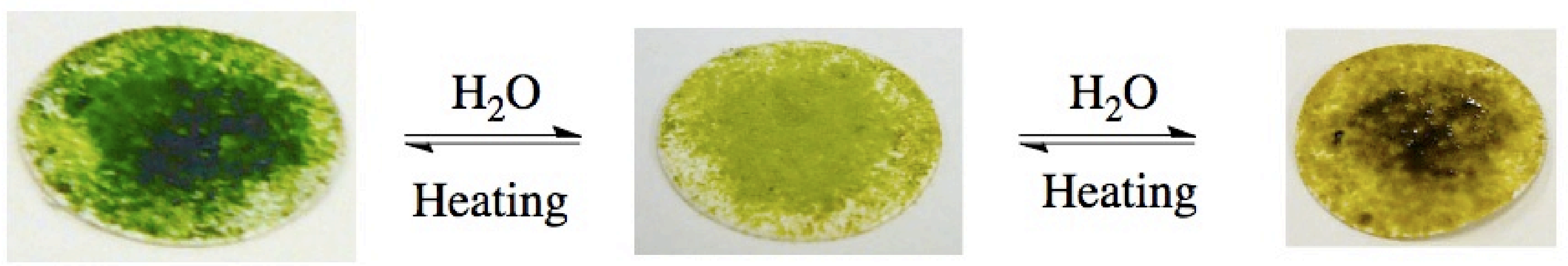

In acetonitrile

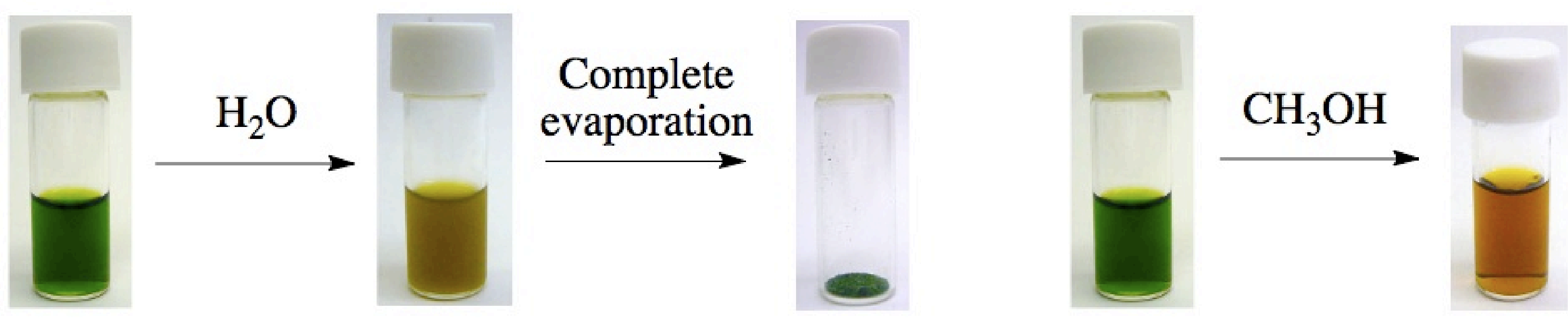



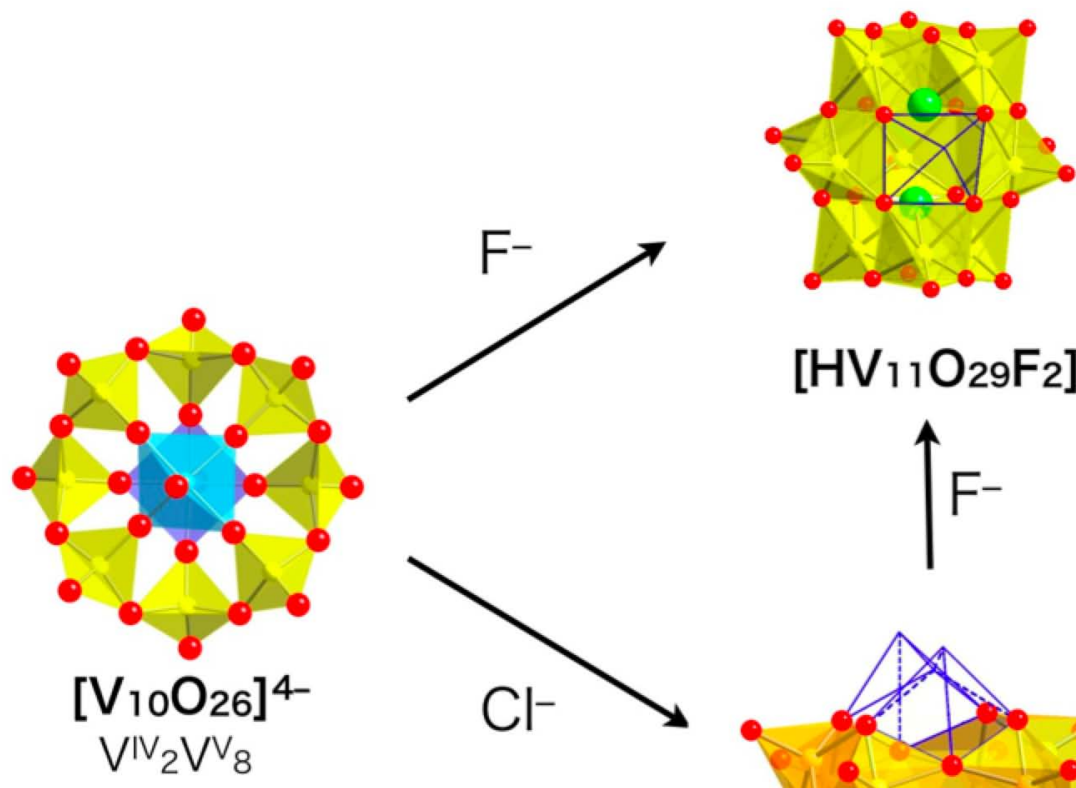

$\left[\mathrm{HV}_{11} \mathrm{O}_{29} \mathrm{~F}_{2}\right]^{4-}$
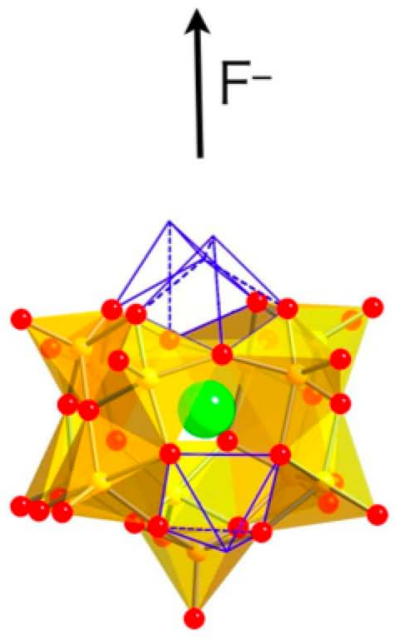

$\left[\mathrm{HV}_{12} \mathrm{O}_{32} \mathrm{Cl}\right]^{4-}$ 


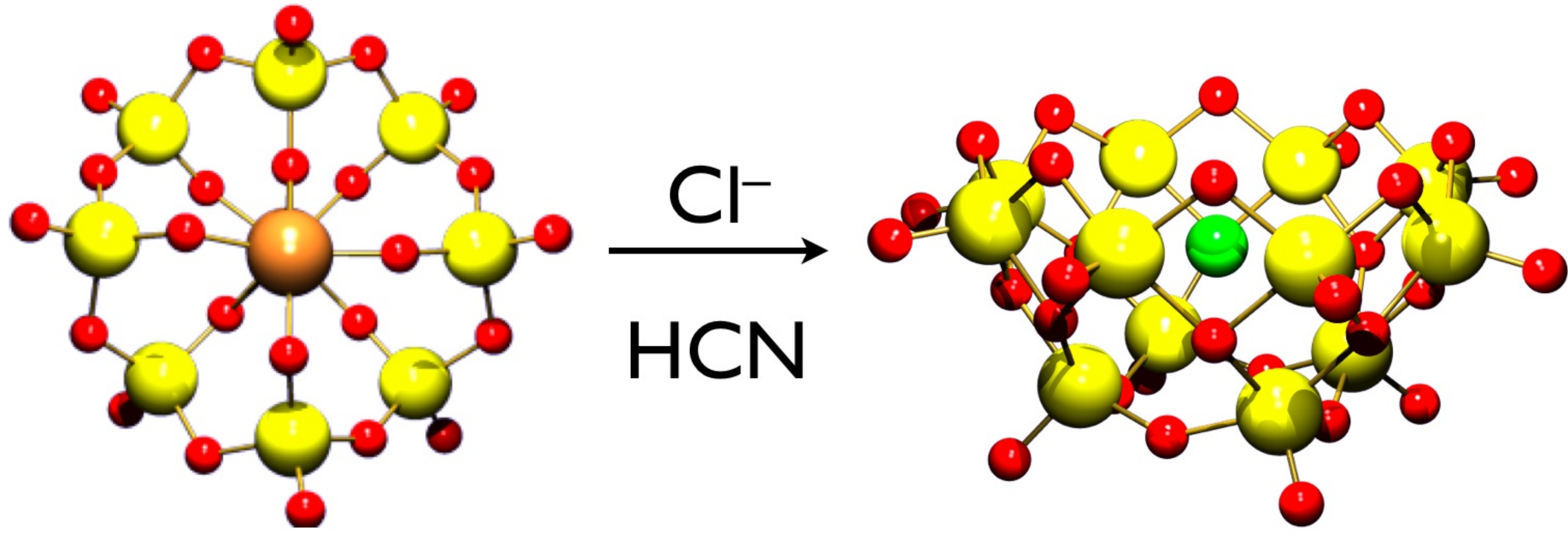

$\left[\mathrm{Cu}_{2}\left(\mathrm{~V}_{8} \mathrm{O}_{24}\right)\right]^{4-} \quad\left[\mathrm{V}_{12} \mathrm{O}_{32}(\mathrm{Cl})\right]^{5-}$ 